\title{
HIV and Other Sexual Transmitted Infections-Challenges for Liberal Prevention Strategies
}

\author{
Reinhard H. Dennin1,2, Michael Lafrenz², Georg Gesk ${ }^{3}$ \\ ${ }^{1}$ Institute of Medical Microbiology and Hygiene, University of Luebeck, Campus Luebeck, Luebeck, Germany \\ ${ }^{2}$ AIDS Medical Board, Medical Association, Rostock, Germany \\ ${ }^{3}$ Department of Law, Hsuan Chuang University, Hsinchu, Taiwan \\ Email: reinhard.dennin@uk-sh.de
}

Received 17 February 2014; revised 17 March 2014; accepted 10 April 2014

Copyright (C) 2014 by authors and Scientific Research Publishing Inc.

This work is licensed under the Creative Commons Attribution International License (CC BY). http://creativecommons.org/licenses/by/4.0/

(c) (i) Open Access

\begin{abstract}
Many countries use similar strategies in prevention campaigns, but despite that the spread of HIV is unabated. The basic messages of the current liberal prevention strategies aim to promote changes in individual behaviour so as to prevent HIV transmission. The strategies avoid any kind of regulation, prescription and controls, and trust solely on the readiness of the sexually active part of the general population, and in particular the "at-risk populations" to cooperate with those messages. However, only a small number of people have cooperated. The increase in the incidence of HIV over the past decade in the countries listed discloses the failures of the current prevention strategies. With respect to the goal of trying to influence those people prone to high-risk sexual lifestyles, and the injecting drug users, the prevention strategies have not had a meaningful effect in the long term. This is also reflected in the increase of other STIs such as hepatitis C, syphilis, and the human papilloma virus, which are worse when there is co-infection with HIV. The liberal prevention strategies turned out to be inadequate for the goal, and must be adjusted to real life situations to counteract their misuse. Meanwhile there are ample evidence-based measures which must be implemented into concerted efforts by complementing the current strategies with respect to a person-to-person bound infection. Medical care policies have to consider the non-adherence behaviour of those in need.
\end{abstract}

\section{Keywords}

HIV, STI, Prevention, Liberal Prevention Strategies 


\section{Present State}

In its HIV/AIDS surveillance report for Europe in 2010, the European Centre for Disease and Prevention Control (ECDC) states: "HIV infection remains major public health importance in Europe, with evidence of continuing transmission in Europe. Overall there is no clear indication of a decline in the number of cases being diagnosed each year and HIV continues to be concentrated in key populations at higher risk (e.g., people who inject drugs and their sexual partners; men who have sex with men and migrants)" [1]. The data presented by the ECDC/WHO demarcates "...heterosexual transmission is the main mode of transmission in the entire WHO European Region but sexual transmission between men is the most common mode in the EU/EEA” ([2], a) and "In the EU/EEA, the predominant mode of transmission for HIV is sex between men, followed by heterosexual contact” ([2], b) for the western part of Europe, whereas in the more eastern parts heterosexual transmission and injecting drug use (IDU) predominate [2]-[4]. The data shown for 2011 continue with about the same pattern in 2012. "Men who have sex with men (MSM) in Europe (...) are disproportionally affected by HIV and STI. This risk is heightened by high levels of unprotected anal intercourse among MSM and extensive sexual networking..." [5]. This development is happening in contrast to statements in the ECDC technical report from an internet survey that “...MSM in Europe care about HIV and sexual health issues” [6]. Data from the pan-European SPREAD project show that 1) The most commonly reported transmission groups were MSM (48\%), followed by heterosexuals (35\%); 2) MSM did less often cluster with patients from the same country than heterosexuals and injection drug users, i.e., those people who acquired their HIV infection from partners in other countries [7]; and 3) In addition, consequences arising from imported non-B subtypes into Europe are increasing the odds for recombination in the case of double infection with HIV of different clades resulting in circulating recombinant forms (CRFs).

For the USA, the "CDC estimates that 1,144,500 persons aged 13 years and older are living with HIV infection, including 180,900 (15.8\%) who are unaware of their infection..." and "Gay, bisexual, and other men who have sex with men (MSM), (...) are most seriously affected by HIV” [8]. The trend of increasing risk behaviours among MSM in the USA and Europe in the recent years should alert designers of prevention campaigns [9].

The latest reports from France [10] as well as from the UK [11] and Germany [12] also show MSM being the most affected population. As with the ongoing spread of HIV in the western hemisphere by members of this sexually risk-prone ${ }^{1}$ group, MSM likewise contribute to the disproportional spread of HIV in Brazil [13].

In the broadest sense, these developments reflect the reinvigorating trends of increasing high-risk sexual attitudes in those subgroups ${ }^{2}$. The "Global epidemiology of HIV infection in men who have sex with men" underscores the impact of this group in the as yet uncurbed spread of HIV [14] and discloses inadequate prevention issues. "Perhaps the greatest challenge in terms of prevention has been in the global community of MSM in which HIV remains endemic at high prevalence" [15]. UNAIDS stated: "The prevalence of HIV infection among men who have sex with men in surveys in capital cities is on average 13 times higher than that in the country's general population. Studies in East Asia suggest rising trends in HIV prevalence among men who have sex with men, and some evidence indicates that the global prevalence of HIV infection among men who have sex with men may have increased from 2010 to 2012, although data are limited and the use of diverse study methods creates difficulty in comparing results across settings and time” [16]. The HIV epidemic in China is on the rise too [17]. Initially it was driven by injecting drug users (IDU) but has reached the other at-risk groups as well [17] [18].

There are almost overlooked issues, e.g., 1) the youth in the USA [19]; 2) almost all papers mentioned above point to the large proportion (mostly more than 20\%) of people who don't know about their HIV infection but are "at-risk"; 3) the risk of HIV transmission by unprotected anal intercourse (UAI) between MSM vs. UAI be-

\footnotetext{
${ }^{1}$ High-risk, e.g., “.... considerable percentage of seropositive persons (...) continue to engage in unprotected sexual behaviors that place others at risk for infection and place themselves at risk for contracting secondary infections...” (Crepaz, N. and Marks, G. (2002) AIDS, 16; 135-149). This needs complemented in that sexual promiscuity itself poses a risky behaviour because this includes the potential of acquiring STIs. "Risk factors such as multiple sexual partners, high rate of partner change, unprotected anal intercourse and oral sex have been key factors in the accelerating STI and HIV transmission rates among MSM in Europe...”

http://ecdc.europa.eu/en/publications/publications/sti-hiv-prevention-msm-in-europe-21-feb-2013.pdf

2“Key populations" and "Most-at-risk populations are defined (...) as men who have sex with men, transgender people, people who inject drugs, sex workers and prisoners...” http://whqlibdoc.who.int/publications/2011/9789241501651_eng.pdf

http://ecdc.europa.eu/en/publications/publications/20121130-annual-hiv-surveillance-report.pdf

http://www.euro.who.int/_data/assets/pdf_file/0011/153875/e95953.pdf
} 
tween heterosexual partners should become a topic in prevention concepts as well [20].

"Despite great progress in tackling the HIV epidemic worldwide in the past two decades, there is one population in which the epidemic continues to grow in countries of all incomes: men who have sex with men (MSM)" [21]. "HIV epidemic spread among MSM is occurring in both high, middle- and low-income settings..." [22]. "Epidemics of HIV in men who have sex with men (MSM) continue to expand in most low, middle, and upper income countries in 2013 and rates of new infection have been consistently high among young MSM. Current prevention and treatment strategies are insufficient for this next wave of HIV spread" [23]. In this context, the deliberate use of the internet to look for partners who are ready for high-risk practices indicates intentional noncompliance with the current prevention efforts [24].

How could this happen? At first it is important to note that MSM are not a cohesive group in themselves because of differences in, for example, ethnic background, education, awareness of the adverse consequences once infected by HIV, and furthermore the homeless people. Comments from recent scientific papers aim at “...reinvigorated trends engaging into increasing risk behaviour..." which reflect a deliberate intention of engaging in such high risk attitudes and thereby oppose the correct prevention messages.

"Estimates of risk behaviours and the incidence of HIV among MSM before and after the introduction and expansion of ART suggest that the population-level protective benefits of ART (TASP strategy, Chapter 4.3.) may be attenuated by a number of factors, most notably, continuing or increasing frequency of condom-less anal intercourse and incidence of other sexually transmitted infections (STIs)" [25].

"Homosexual men continue to report increasing levels of UAI. HIV prevalence is high in this group, with many infections remaining undiagnosed. The high level of risky behaviour in HIV positive men, regardless of whether they are diagnosed, is of public health concern, in an era when HIV prevalence, antiretroviral resistance, and STI incidence are increasing” [26].

"In the last decade, major shifts toward increasing HIV risk behaviour have been reported in behavioural surveillance studies of MSM (...)", and "These trends have been followed by increasing rates of sexually transmitted infections..." [27]. This report also considers bisexual men who may operate as bridging people with female partners. "In the 1990s the introduction of combination antiretroviral treatment turned HIV from a death sentence into a chronic disease, and it is thought that this may have created a sense of complacency and an increase in high-risk sexual activity” [28]. Such intentional high-risk behaviour must not be linked to discrimination. Instead, discrimination is often used to justify the misuse of the liberal prevention strategies.

Furthermore, in European countries, as well as in the US, it's not the HIV alone that bothers public health; other STIs have to be considered too in this context, whether as a single-agent infection or co-infections with HIV such as Hepatitis C. The ECDC has acknowledged that in the European Union and the European Economic Area (EU/EEA) "....men who have sex with men (MSM) are disproportionately affected by HIV and other sexually transmitted infections (STI)” [29].

\section{Other STIs-Not HIV Alone-Will Challenge the Resilience of the Economy}

\subsection{Hepatitis C Virus (HCV)}

The latest report on the global burden of HCV claims that $2 \%$ to $3 \%$ of the world's population is infected, i.e., 142 to 213 million people; this amounts to approximately six times the number of people living with HIV, but no HCV related prevention campaigns exist [30].

Like HIV and HBV, the basic sources of transmission for HCV are blood-borne. These include transmission via sexual practices (classifying it as a STI), but there are differences in the efficiency of transmission by heterosexual activity_ “....an extremely infrequent event” [31] and “....an increased risk for sexual transmission of Hepatitis C among gay men who are HIV-positive" [32]. HCV also has a high risk potential owing to parenteral infection, e.g., injecting drug use [33]. However, "Injection overuse and unsafe practices account for a substantial burden of death and disability worldwide." have to be taken into account [34]. "Semi-sexual" practices such as fisting in settings independent of sexual orientation may turn out to be of particular concern. This is because these practices often involve specific sex toys and lifestyle drugs [35]. The latter are consumed to ameliorate pains due to, for example, rough sexual practices that may lead to rectal or vaginal bleeding, respectively (resp.) and more [36] [37]. Those toys can serve as "vectors" when shared among participants by transmitting HCV contained in blood smears mixed with mucus, i.e., indirect transmission of HCV. Such kind of contaminations may support the transfer of HCV because it has turned out being considerably resistant against inactivation in 
water, plasma and on surfaces of different kinds [38]-[40].

The adverse effects of the HIV infection itself in the final stage of AIDS are well documented. However, for people bearing HIV/HCV co-infections the conditions worsen [41]-[43]. HIV/HCV co-infections are prone to posing more complex challenges for patients, for example by worsening the progress of end stage liver disease [44] [45]. The risk of acquiring HCV is higher in HIV-positive MSM than HIV-negative MSM, thus pointing to a kind of cluster spreading through those with high-risk behaviour [46]-[49]. Such "cluster eruptions" are indicative of those people involved avoiding preventive measures. In order 1) to curb the spread of HCV in MSM communities and 2) being able to provide specific medical care for them, additional screening and counselling projects for HCV should be offered to these people in particular [50]-[52]. This has to be seen in conjunction with the high HCV reinfection rates in HIV-positive patients, in particular MSM [53]. This phenomenon has been linked to ongoing "at-risk" practices and has to be taken as an indication of the attitudes of non-compliance with preventive measures [54]. As with HIV, there is already considerations of a screening of HCV in adults [55] and IDU [56].

\subsection{Hepatitis B Virus (HBV)}

HBV also causes blood-borne infections and shares modes of transmission with HIV and HCV although these vary depending on the geographic area [57]. The awkward side effects show up in cluster situations [58].

An effective vaccine exists, and therefore screening for HBV should be offered to the people most at risk [59], as in 2). Vaccination against HBV should be recommended to "HBV-negative" tested people and those who need booster immunisations.

\subsection{Syphilis}

Because there are high rates of syphilis in MSM [60] certain stages of this STI give excellent grounds for acquiring HIV. If syphilis remains undiagnosed and untreated, neurosyphilis can develop and is more serious than syphilis as a mono-infection [61]. Syphilis [62] [63] is on the rise in China as well [64].

\subsection{Human Papilloma Virus (HPV)}

Regarding the HPV there is growing concern for MSM [65]. This is not just pertaining to the "increased risk" of acquiring HIV if already infected by HPV [66] and vice versa [67], but also due to "anal intraepithelial neoplasia cases" [68]-[70] , and HPV-associated oropharyngeal squamous cell carcinoma (SCC), in particular pertaining to MSM and other people practicing oral sex activities [71]. A vaccination is available to prevent infection of the most serious HPV genotypes 16 and 18. Cost-effective studies and guidelines are needed for offering it to MSM in particular, and sex workers [72].

\subsection{Herpes Simplex Virus (HSV)}

Only a few studies address the impact of genital shedding of herpes viruses contributing as a cofactor for HIV-1 transmission [73] [74]. This virus infection also has to be incorporated in behavioural intervention programmes in view of changing and extending genito-ano-oral sexual practices.

\section{Prevention}

\subsection{General Aspects}

The paradigm behind the current behavioural intervention concepts of the HIV prevention strategies applied in numerous countries since the late 1980s is largely based on "social learning strategies" in context with the New Public Health (NPH) [75]. This is in contrast to the [Old] Public Health principles which followed "...traditional disease-control principles and proven interventions that can identify infected persons, interrupt transmission...” [103] and that should apply to the strictly person-to-person bound HIV transmission. Instead, the new liberal NPH concepts focus on popular information, counselling and sex education about risk-reduction intervention only. These concepts have been complemented with practical hints about physical prevention practices such as "condomise" ${ }^{3}$ and safe use regarding IDU for avoiding the spread of HIV.

\footnotetext{
${ }^{3}$ An initiative presented at the $18^{\text {th }}$ International AIDS Conference, Vienna 2010, Austria.
} 
Such concepts mismatch the mode of HIV transmission with that of a community acquired infection such as influenza.

\subsection{The Viewpoint of Infectious Disease Medicine}

Programme and decision makers have classified the HIV infection (primarily a STI) into an exceptional status, although it is comparable with HBV and (several years later) HCV infection, example given due to shared routes of transmission, and seriousness of disease in the long-term prognosis, but without any exceptionalism for HBV and HCV. By defining the HIV infection as "exceptional", those populations most at-risk and already infected by HIV in turn were stigmatized in a manner that amounted to a kind of social dislocation.

The social aftermaths are obvious: instead of focusing on HIV positive individuals and those at-risk to integrate them into community-based networks thus being able to provide them help with precise information on their particular risky behaviours, emphasis of the prevention campaigns has targeted the general population, the vast majority of whom are uninfected. Almost as a consequence in particular the most at risk people and those already HIV infected of the different groups addressed here, were marginalised and developed their own networks (which may overlap). In view of MSM networks in the context of the increasing prevalence of HIV infected MSM concentrated epidemics may develop in these particular at-risk communities with a critical threshold of HIV-infected people, thereby increasing the odds for an acceleration of the spread of HIV within such networks, such as “...linked clusters...” [14]. The respective data given by UNAIDS [16] are too low according to other sources (Table 1). Depending on regional situations the relation "prevalence of HIV in MSM communities vs. the general population" reaches 30 times at least. This has to be seen with cluster effects concerning IDU likewise. Regarding the situation of MSM in a multi-country survey see [76].

The designers of prevention campaigns didn't seriously consider a crucial issue: "Preventive interventions with positive individuals are likely to have a greater impact on the epidemic, for an equivalent input of cost, time, resources, than preventative interventions focused on negative individuals. A change in the risky behaviour of an HIV positive person will, on average, and in almost all affected populations, have a much bigger impact on the spread of the virus than an equivalent change in the behaviour of an HIV negative person" [77].

However, far too many of the at-risk-prone people were, and still are, not poised to implement the correct messages of the prevention campaigns to change their behaviour regarding sexual partnerships respectively sex for fun and drug use to prevent the transmission of HIV. Far too many of these people are not willing to cooperate, but instead they intentionally continue in high-risk behaviour practices such as unprotected vaginal and in particular MSM - anal intercourse (UAI) resp. Such kind of behaviour cannot be attributed to any kind of discrimination resp., stigmatization. The anatomical structure of the GALT should be considered when comparing different HIV transmission rates when practising UAI during vaginal sex vs. anal intercourse [78].

Table 1. Changes of the Prevalence of HIV infected people from 2000 to $2012^{*}$.

\begin{tabular}{|c|c|c|c|c|}
\hline Region & Year & $\begin{array}{c}\text { Estimated adults and children } \\
\text { living with } \mathrm{HIV}^{*}\end{array}$ & $\begin{array}{l}\text { Adult (15 - 49) } \\
\text { prevalence (\%) }\end{array}$ & HIV prevalence among MSM $^{* *}$ \\
\hline \multirow{2}{*}{ East Asia } & 2000 & 320,000 & $<0.1$ & \multirow[b]{2}{*}{ no data given } \\
\hline & 2012 & 880,000 & $<0.1$ & \\
\hline \multirow{2}{*}{ North America } & 2000 & 940,000 & 0.5 & \multirow{2}{*}{$\begin{array}{l}\text { USA, } 20 \text { cities, 2011: 18\% }{ }^{\mathrm{a}} \\
\text { Canada, cities, 2011: } 11 \%-23 \%{ }^{\mathrm{b}}\end{array}$} \\
\hline & 2012 & $1,300,000$ & 0.5 & \\
\hline \multirow{2}{*}{$\begin{array}{l}\text { Western and Central } \\
\text { Europe }\end{array}$} & 2000 & 570,000 & 0.2 & \\
\hline & 2012 & 860,000 & 0.2 & $\begin{array}{l}<1 \% \text { to }>5 ; \\
\text { in certain countries }>10 \%{ }^{\mathrm{c}}\end{array}$ \\
\hline
\end{tabular}

*Source: UNAIDS Report on the Global AIDS Epidemic-2013. HIV Estimates with Uncertainty Bounds, 1990-2012. *Uncertainity Bounds Have Been Omitted Here. http://www.unaids.org/en/dataanalysis/knowyourepidemic/epidemiologypublications/ ${ }^{* *}$ More data [14]. ${ }^{\text {a} P a g e ~ L a s t ~ U p d a t e d: ~}$ September 26, 2013. http://www.cdc.gov/hiv/risk/gender/msm/facts/index.html

bhttp://www.catie.ca/en/fact-sheets/epidemiology/epidemiology-hiv-gay-men-and-other-men-who-have-sex-men ${ }^{\mathrm{C}}$ ECDC 2013, Thematic Report: Men Who Have Sex with Men (MSM)-Monitoring Implementation of the Dublin Declaration on Partnership to Fight HIV/AIDS in Europe and Central Asia: 2012 Progress.

http://www.ecdc.europa.eu/en/publications/Publications/dublin-declaration-monitoring-report-men-who-have-sex-with-men-october-2013.pdf 


\subsection{Apparent Unfitness of the Current Concepts}

The mono-thematic straightened concepts regarding the prevention of the HIV infection try to influence individual behaviour by targeting complex emotionally based behavioural patterns with cognitive level based messages according to the rules of logic. Contrary to reason it was anticipated that intellectually based messages targeting the cognitive level would be effective in achieving a long-lasting control on intimate behaviour. Programme and decision makers have neglected reality in that 1) the real behaviour in discussion is based on a very emotional level; and 2) superposed by, for example, ethnicity, education, psychological distress, and culturally coined and traded behaviour right up to modern risky lifestyles. Decision makers have further neglected the complexity of situations. For example, with respect to the great variety of people, ranging from loners up to those people who have self-organised into real and virtual sexual networks, i.e., they have organised themselves. Such networks may boost group dynamics thereby fostering social interaction and promoting their own norms, example given by peer pressure. Furthermore, those "learning concepts" have failed in the context of responsibility for partners and the community, and to include those people who are not able to understand the messages.

Could behavioural intervention strategies have long-term influence on people driven by their sexual urge and in particular the most at-risk population responsible for the increasing HIV incidence in Europe, North America and elsewhere [79]-[81]? However, there are controversial experiences which have to be taken into account [82]. Studies into “...multi-component intervention...”, albeit with a small sample size, showed a successful sustainability effect [83]. All groups addressed here require professional counselling from someone experienced in structured individual “one-to-one”, as well as group therapy/counselling [84]-[87].

The basic statements, "Current prevention efforts have been unable to contain or reduce HIV transmission in this population" [88]; and "Current prevention and treatment strategies are insufficient for this next wave of HIV spread” [23] are sobering and should encourage policy makers to adjust current prevention strategies.

\subsection{Transnational Projects}

According to UNAIDS, prevention strategies of a different kind seem to work to some degree in various countries, [89] although recent data don't fit with this [90]. "AIDS is not an exceptional disease; it is an exceptional opportunity. Part of the reason for a change in strategy is a matter of brutal reality” [91]. In the context of "AIDS is not over" [92], it is an unspoken admission of the inefficient prevention campaigns promoted thus far, and should be a poignant call to awareness for programme and policy decision makers. Prevention planners and decision makers have to provide answers to questions such as: How can we reach those persons who exploit the liberal prevention concepts for selfish benefit? How can we redirect the subsets of people mentioned in Chapter I, bringing them to awareness in view of personal responsibility? At present the situation seems to be stalled to members of all of the above parties and groups.

The Global Health Sector Strategy on HIV/AIDS 2011-2015 presented by the WHO provides an improved strategy of prevention by implementing “...four strategic directions, each composed of core elements” [93]. However, the programme planners and decision makers at the WHO have focused on HIV, and by the way on tuberculosis (Tb) too, but have not considered the other STIs which are accepted as serious co-factors in HIV transmission, and co-morbidities. Their complex interactions require constant attention to all concomitant factors involved when addressing investments for screening and behavioural intervention programmes.

\subsection{Subsuming the Epidemiological Facts and HIV Prevention Issues}

The liberal prevention strategies rely on people who are willing and able to behave responsibly, in the sense of self-discipline which has to be de rigueur for all concerned. But decision makers have denied the realty of the extreme idiosyncrasies of human behaviour. The statement of the ECDC regarding the increase of STI and HIV clearly marks the failure of the current prevention strategy wherever it has been applied: "The increase of risky behaviour was reported to be associated with treatment optimism and cART fatigue, as well as improved quality of life of HIV-infected MSM. Negotiated safety trends such as strategic positioning, serosorting, and withdrawal are increasingly reported, but these are not necessarily effective risk reduction strategies. This trend poses new challenges for HIV and STI prevention, requiring an evolution of interventions to remain effective” [29]. There's the rub [94]. 
These liberal concepts are not linked to any personal constraints or official sanctions.

As a consequence the people who continue to spread HIV are essentially shielded by anonymity, for example, there is no-name reporting, no partner-notification if someone is HIV positive. The review of the ECDC on the lack of "partner notification" in many countries of the EU shows the negligence of those responsible for Public Health matters [95]. Partner-notification has turned out successfully to contact people unaware of their HIV infection [96].

Those responsible have failed to realise the complexity of the behaviour in particular of those most at risk people, example given, counteracting the messages of the prevention campaigns which are the prerequisites in the proper sense of a conditio sine qua non [97]-[99].

The liberal tenets of the current prevention strategies are inadequate to curb the spread of HIV by subpopulations willing to undertake high-risk prone sexual behaviour. This kind of strategy equals an experiment that has never before been tried, and is done without the concept of a controlled study at such a scale [100], i.e., without any evidence-based concepts on hand.

The assumptions have turned out to be fundamental misconceptions for such a task and have failed in their stated goals. Decisions makers responsible for enacting these strategies by focusing only on liberal attitudes have failed to reveal faults. By contrast, they maintain the defaults and so continue to provide protection for the misuse of liberal tenets and prolonging the ongoing spread of HIV in general.

\section{What Remains to Tackle the Crisis of the HIV Prevention?}

\subsection{Facts}

The programme and decision makers of the current prevention campaigns have focused primarily on the interests of the individual but have neglected the interests of the societies which have to pay for individual failure. Improved prevention concepts have to consider concepts balancing between the entitlements of people at risk and already affected by HIV, resp., and those of society.

\subsection{What Kind of a Strategy?}

We suggest combining different measures known thus far for a comprehensive, multisectoral strategy, and having in mind the reality of human behaviour and the diversity of the target groups. 1) The programme-makers responsible for shaping new prevention strategies must acknowledge the reality of human behaviour, i.e., not only follow liberal strategies promoting and relying on an individual's own responsibility thereby tolerating the spread of HIV; this was the wrong directive. 2) The only chance seems to balance new strategies: including the rules of an open society and more restrictive measures based on unprecedented concepts. Different elements for a new comprehensive prevention strategy must be combined following a rational background [101] [102].

A public health initiative is required to alert the general population, and to encourage people at risk to ask for an HIV test. Such campaigns should clarify to the public that ART/HAART is not a cure, as many believe, and may have side effects. Designers of such programmes should implement the messages outlined by del Rio [138].

The "exceptionalism" of the HIV infection has to be reversed and HIV should be handled the same way as for Hepatitis B and Hepatitis C: "AIDS is not an exceptional disease" [91] [103]. Such a change would help to "normalize" HIV infection thereby both terminating the HIV/AIDS "exceptionalism" and reducing the effect of stigmatization.

\subsection{The Biomedical Approaches and More}

\section{- The TASP Approach and More Using cART}

New hope for curbing the ongoing spread of HIV came with the "Treatment as Prevention" strategy [TASP]. People diagnosed HIV-positive can be offered a cART. Beyond the benefit of improving their health condition, there is an agreement that cART can reduce the viral load of HIV in blood [VL] thereby decreasing HIV infectiousness [104]. This applies to the population-level, i.e., the "community viral load" [105], and thereby can help curb the spread of HIV. But such a statistical connection seems to be too simple as different influences may affect the results [105]. Nevertheless, patients concerned must pay attention to certain framework conditions, such as other STIs [106]. Furthermore, in spite of cART the HIV-containing secretions in the female and male genital tract [107] [108], different HIV-1 subtypes may balk hopes [109]. Further reports about the reduction of infec- 
tiousness by TASP should remind health care providers to improve the guidelines for patients [110] [111]. This concerns people who left medical continuous care for various reasons and may contribute to HIV transmission [112]. Further attention needs to be given to possible drawbacks [113]. A study in China showed the importance “...an urgent need..." if patients are identified earlier after HIV infection and are successfully linked with care, cited in [113].

The new guidelines published by the WHO, to treat HIV infected people earlier in the course of HIV infection [114], have to be considered in behaviour counselling tasks including controversial aspects regarding the possible benefits for patients [115]. However, the occurrence of ART resistant HIV deserves increasing awareness [116] [117]. The WHO already warns: "Significant population-level HIV drug resistance could potentially restrict future therapeutic options and increase treatment costs by requiring new and more expensive antiretroviral regimens" [118]. A study showing HIV infected individuals transmitting drug resistant (TDR) HIV, although not yet treated with cART, indicates the non-compliance of cART treated people with regard to preventive measures [119].

\section{- The "Antiretroviral Pre-Exposure Prophylaxis...” (PrEP)}

The strategy is to provide PrEP treatment as "...a new prevention intervention in which HIV-uninfected people take a daily dose of antiretroviral medication to lower their chances of acquiring HIV" [120]. This kind of a prevention cocktail may lead people at risk to a complacent and careless behaviour. Messages of that kind need to be complemented with information about the detrimental effects of being infected with HIV and the potential harmful side effects of the drugs in the long-term.

\section{- The Post-Exposure Prophylaxis (PEP)}

For several years this strategy was propagated for occupational settings (example given, needle stick dependent situations for health care workers) and HIV-negative people after "risky sex".

\section{- Help for IDU}

A study about IDU in Bangkok and Thailand looks promising in reducing the sexual transmission of HIV [121]. In this context the invention of the "low dead-space syringes" for IDU may also be a prospect for reducing HIV transmission when sharing needles [122]. The CDC/USA has published recommendations, "Integrated Prevention Services (...) for Persons Who Use Drugs Illicitly...” to improve the situation for IDU [123]. As well as HIV it covers both other STIs and tuberculosis. This constitutes a necessary measure to help those people. The peer-to-peer prevention programmes need more studies [124].

\subsection{People Who Are Unaware That They Have HIV}

These people contribute considerably to its transmission. How can they be found [125]-[127]? Given the alarming epidemiological data which undoubtedly shows a rampant increase in HIV infection disproportionately in the MSM group, any kind of new testing strategy has to focus on them. Meanwhile, it seems like a common sense to introduce a kind of routine HIV testing offered by healthcare providers at hospitals and practitioners. In view of cost-effectiveness the current testing strategy is called into question in favour of a more differentiating one [128]. The ECDC strategic priorities address general aspects as well "Concerning the control of HIV, STI and hepatitis, prevention efforts need to be enforced and, in some areas, new and innovative methods need to be developed and evaluated" [129].

The US Preventive Services Task Force (USPSTF) recommends a HIV testing in "....adolescents and adults aged 15 to 65 years. Younger adolescents and older adults at increased risk...” and “...pregnant women...” [130]. Such a strategy seems without any alternative—why is it justified to do so? At present, the actors especially belonging to the at-risk subgroups addressed here continue their risky behaviour, thus spreading HIV. Parts of them cannot understand the accurate prevention campaigns, and are not able to understand contextually the messages specified therein, while the other people ignore them, and knowingly or negligently continue to spread HIV. In particular this USPSTF initiative marks a remarkable step to reach those people independent of their risk for HIV testing and might eliminate their fear of getting stigmatized [131] [132]. The new USPSTF recommendations meet the ambitious goals of the WHO's guidelines “...people living with HIV must be diagnosed and linked to care early in the course of HIV infection” [114]. This also meets the search for new strategies for HIV testing in the EU to reduce the number of late presenters [133].

A vital necessity in adapting HIV testing policies is seen in the P.R. China [134]. Real-name testing is con- 
sidered necessary to reduce the rates of people who don't know about their HIV-positive status [135]. In general, this measure to enforce HIV testing will only be used to trace sources of unknown HIV-infections to provide them with counselling and medical care.

But will this work on a liberal modality thereby sheltering the inconsiderate behaviour of the subsets of "at risk" people, allowing them to continue in their vested interests? The experience so far should encourage reconsideration of a more "aggressive" strategy, as considered by several authors. This is a consequence of the non-compliant attitude of those actors contributing to the ongoing spread of HIV [136]. A recent report again highlights the problems to provide help of a different kind to MSM which is of limited effectiveness [137]. The report on "Understanding and Addressing Cultural and Socioeconomic Barriers to Effective HIV Management" [138] highlights the incorrect handling and categorisation of the HIV infection since the beginning of the epidemic by making the HIV infection an exceptional STI instead of handling it as a regular STI such as HBV. "HIV-prevention science at a crossroads" (...) and "have failed to reduce substantially the global pandemic" [139]. That's a quintessence—-but true also in context with the global burden of HIV [140].

A community-based approach, forwarding a comprehensive prevention and treatment strategy, has been established in the P.R. China. It uses the "Network of community physicians connected with residents" and covers a broad spectrum of severe infectious diseases (SIDs), such as tuberculosis, hepatitis and HIV/AIDS [141]. This project forwards the integration of people with HIV into communities.

Health care providers need to cooperate so as to offer all index patients "...structured intervention (such as motivational interviewing or counselling) when attending their sexual health clinic...” [142]. Such strategies can work, as shown in "...one-on-one or group skill-building interventions..." and "There is a growing consensus that merely providing information is not enough to induce sexual behavior change...” [143].

Despite the basic good news that intensifying HIV testing can help reduce HIV incidence in the group of MSM/UK [144], a mathematical model provides conflicting data about whether increasing test frequency for HIV and treatment can result in lower HIV incidences in MSM, and "Moreover, these benefits are counterbalanced by large increases in Multiple Drug Resistance (MDR)" [145] and the increase in transmitted drug resistance (TDR) due to "Patients who engage in ongoing risk behaviour..." [146] that communities will be faced with.

\section{Appraisal of the Judicature}

General points of view: the current prevention strategies are grounded on liberal concepts throughout. They haven't provided effective allocated directives/functions for enforcing sustainable changes in individual behaviour, in particular for the most affected target groups. The interconnection of no-name reporting of an HIV-positive test, no mandatory duty to disclose his/her HIV-positive status to partner/s [147] [148], and the actions for decriminalization of HIV transmission (apart from intentional transmission), provides a protection to those who continue to spread HIV anonymously, i.e., without the necessity of taking up personal responsibility for themselves and partners. A background paper by UNAIDS discusses different views of HIV infection in this context [149].

The UNAIDS initiative on the "Decriminalization" of HIV transmission in different countries outlines the different measures, and jurisdiction in case of HIV transmission.

More specifically, political decision makers have not thoughtfully considered real life issues. Instead their decisions tolerate the assaults made by means of HIV infection, and the lethal consequences, thereby neglecting duties to the communities they are committed to by virtue of legislation.

\subsection{The Juridical Situation in Germany}

The strategy of decriminalization suggests that normally a penalty has to be imposed, only because a person is infected and intentionally transmits HIV to a partner. From the outset, such a criminal law would not penalise unlawful acts, but rather the bodily constitution of a person, which would breach the link between criminal law and unlawful acts. The German criminal system is based on the idea that a penalty shall only be imposed on the grounds of an unlawful act. Nevertheless these unlawful acts can be related to the persons' physical constitution, such as the case with diseases.

In such a case, the principle applies that any violation is prohibited if the violation is committed by an unlawful act. Thus, somebody with a serious illness transgresses the generally tolerated risk area if they intentionally 
or negligently infect other people. Admittedly, it is often difficult to establish that the act of a certain person has caused the transmission and thus that a crime has been committed. Additionally the confidence into a good ending which for example can be based on the habituation effect of risky behaviour can lead to the fact that at least intention can be precluded.

As a consequence, many legal systems have established a new category of criminal offence. These offences still do not penalise a person's physical condition, but a person's unlawful act. Yet, the offences do not require harm (death, injury, etc.) to have arisen; so that the person's mental elements of the offence can comprise the harmful act. One might describe these offences as penalising the imperilment, not just the actual impairment of a certain legally protected right. As a result, the procedural problems of having to prove causation and intention in relation to a particular harm do not arise. Concerning the dogmatics of criminal law, in such legal systems one can perceive a coexistence of offences that require a harm to be inflicted and those that do not. This might only be of subsidiary importance. This means that the latter will only apply if it cannot be established that the classical offences of homicide and assault have been committed. In the jurisdictions that do not know strict liability torts, only the traditional statutory offences for the protection of life and physical integrity apply. What does "decriminalization" mean in different legal systems? For those legal systems that acknowledge imperilment as an element of an offence, the abolition of these offences would cause the traditional offences of homicide and assault to be applied for those acts again. The unlawful acts are not therefore legalized, but the standard of proving a crime to have been committed will rise to its former level. If the decriminalization was implemented further, so as to exempt criminal liability for intentionally or negligently transferring HIV within these traditional offences, the legislators would be obliged to give good reasons why certain acts that lead to criminally penalized injuries can no longer be punished. In Germany's legal system, this is out of question. There can be no explanation for penalizing, for example, negligently causing physical injury while driving as a traffic offence, when the negligent transmission of the HIV virus remains unpunished. Neither could this be dogmatically justified or reconciled with the ordinary law or constitution. Consideration is given in the UK of "the ongoing controversy regarding the prosecution (...) of people living with HIV who do not disclose their HIV positive status to sexual partners" [150].

"Specific attention should be paid to: travel restrictions, employment, homophobia, sex work, drug control laws and criminalization of HIV transmission. A public-health approach to managing behaviours that put people at risk of HIV acquisition should be promoted as an alternate to criminalization. Sentencing alternatives to incarceration should be promoted as good public health practice” ([93], a).

The crucial point is: UNAIDS is requested to explain adjusting the HIV infection of another person as, for example, grievous bodily harm/bodily injury/whether intentional or not which in view of a decriminalization would infringe and ignore, resp., constitutional rights in certain countries at least [151]. This also infringes Human Rights tenets [152].

"General criminological theory offers at least three main mechanisms through which criminal law is thought to have its effects...” [151] which points towards the impact laws should have as a kind of social control. However, due to an odd pairing of the peculiar features of HIV itself and its new host, the species "Homo sapiens", justice as a yardstick has lost its function to stabilise fundamental legal norms. Political decision makers, by continuing to adhere to the right of self-determination and almost absolute "decriminalization" of HIV transmission, support a trend in which "justice gets lost its normative power in correction of human behaviour". The same applies to social and ethical norms. Except in rare circumstances, if and when occasional cases came up before the court there is no chance to litigate a cause for people who continue spreading HIV in default of a causative evidence for the infection [153].

Therefore, any kind of "decriminalization” of HIV transmission is unappropriated.

\subsection{Imprints of HIV on Chinese Criminal Law*}

Chinese Criminal Law (short CCL) never speaks directly of HIV, but provides for two different kinds of norms that aim at reducing direct or indirect HIV transmission.

CCL Section 360 tries to curb the intentional spread of serious sexually transmitted decease (STD), with the term clearly including HIV when interpreted in accordance with the Administrative Provision Concerning the Prevention from Sexual Decease (性病防治管理办法) Section 2. However, direct intentional transmission of

\footnotetext{
${ }^{*}$ Georg Gesk (葛祥林), Professor and Chairman, Dep. of Law, Hsuan Chuang University (玄奘大学), Taiwan.
} 
HIV through sexual intercourse is only a crime when it is part of prostitution. What is punished is not the actual spread of HIV, but the danger of spreading it. The prosecution does not therefore need to provide evidence of a specific means of infection. If a person knows that he/she is HIV positive and engages in unsafe sex practices without informing his/her partner, transmission has to occur, otherwise CCL Section 234 I (infliction of bodily harm) is not applicable, since legal provisions do not punish a mere attempt. If one person notifies the other before engaging in unprotected sex, intentional harm will be denied by the procurator, regardless of whether harm was inflicted or not ${ }^{4}$.

Unintentional transmission of HIV due to improper handling of blood donations is punishable under CCL Sections 333, 334 concerning illegal selling, or providing blood and related products. Despite these provisions being part of CCL since 1997, isolated instances of patients being infected with HIV still occur in the health care sector 5 .

Since evidence of a causal relationship between unprotected sex and HIV infection may prove rather hard to find in individual cases, and since criminal justice institutions sometimes refuse to enforce arrest warrants when suspects are known to be HIV carriers ${ }^{6}$, some provinces have tried to introduce new provisions ${ }^{7}$ that allow for administrative sanctions against HIV related offenders and thus apply much more lenient rules of evidence, and avoiding criminal trial. It is thus obvious that at least some institutions within China are in favour of legal sanctioning of some forms of spreading HIV. However, due to the very clear decriminalization policy in criminal law, any sanctions have to choose the framework of administrative law.

5.3. A short overview for HIV transmission and the law in England and Wales, see [154].

\section{Last Not Least: The Evolutionary Potential of HIV Itself}

"The key fact about HIV is that it is a non-equilibrium infectious agent” [155]. In terms of steadily ongoing studies on evolutionary aspects of HIV Baltimore's vision was correct, as HIV is going to change its molecular design to fit better with its new host, the homo sapiens. The "...prospects for the human population may look grim...” [156] doesn't seem far-fetched when considering the liberal prevention frameworks supporting HIV's ongoing evolution.

\section{Conclusions}

- The messages of the liberal prevention strategies have to be geared in such a way that people at risk clearly see their potential to improve/change actual behavior. The messages must pay particular attention to immigrants.

- In addition, specific prevention messages for high-risk people have to be developed in order to encourage personal responsibility.

- It is important to have implementation of control measures such as individually based partner notification if one partner tested HIV positive. Therefore, real and virtual community settings should be the appropriate targets. This needs to be attached to requirements.

- However, depending on an unwarrantable and ongoing increase of the prevalence of HIV positive people, the no-name reporting of HIV positive test results has to be replaced by a real name reporting as an inevitable measure. By means of an individually tailored counseling, this measure should only be used for a back tracing, thereby enabling the number of people unaware of their HIV infection to be reduced.

- With respect to the increasing percentages of HIV co-infections with other STI, a routine testing for STI must become a standard, in particular in MSM settings.

- The Treatment as Prevention (TASP) concept and the pre-exposure prophylaxis (PrEP) have to be adjusted for individual patients. Intensive counseling is needed to reduce misuse of the drugs with respect to their behavior.

\footnotetext{
${ }^{4}$ Liu Peizhi (刘培志), Hao Tao (祁涛), How to Classify an Act of Engaging in a One-Night-Stand While Knowing to Be HIV Infected (明知 是艾滋病感染者而与他人发生一夜情的行为定性), The Chinese Procurators (中国检察官), Nov 2012 (160), p. 56 f.

${ }^{5}$ These Provisions Are in Part a Reaction to the Blood Donation Scandal in Henan; despite Having Introduced These Articles into the CCL in 1997, Isolated Cases of HIV Transmission in Hospitals Are Still Occurring; See 19 HIV Positive People In China Win Compensation From Hospital after Contracting Virus from Unscreened Blood, www.medicalnewstoday.com/sections/hiv-aids, 2006-12-08, last visited on 2013-08-31.

${ }^{6}$ Liu Shuang (刘爽), Introduction into Questions Concerning Arrest of HIV Positive Criminal Suspects (浅析艾滋病犯罪嫌疑人羁押问题), Business (商): Forum for Politics and Law (政法論壇), 2012, p. 170.

${ }^{7}$ See Provision against the Spread of HIV of the Guangxi Zhuangzu Autonomous Region (广西壮族自治区艾滋病防治条例) Section 49 in Connection with the National Law on Sanctions for Maintaining Public Order (中华人民共和国治安管理处罚法).
} 
- A routine testing must become a necessary measure because of the manifest non-cooperative behavior of too many at-risk people with the prevention issues. There should be some measures similar to those proposed by the US Task Force Service, the UK, or a "...universal testing...” [157], and enacted according to, e.g., the ratio of regional prevalence of HIV positive MSM vs. the HIV positive people in a certain region. Awareness should be extended to "....specific geographical and drug resistance trends that correlate well with transmission clusters...” [158]. Relevance to the HIV prevalence in the general population only does not take into account the accumulations in vulnerable groups in the respective areas.

\section{Acknowledgements}

We appreciate the cooperation of Prof. Dr. jur. Arndt Sinn for his critical review of the Chapter 5.1.; Centre for European and International Criminal Law Studies (ZEIS), University of Osnabrueck, Osnabrueck 49076, Germany.

\section{References}

[1] European Centre for Disease Prevention and Control/WHO Regional Office for Europe (2011) HIV/AIDS Surveillance in Europe 2010.

http://www.ecdc.europa.eu/en/publications/Publications/111129_SUR_Annual_HIV_Report.pdf http://ecdc.europa.eu/en/healthtopics/aids/Pages/index.aspx

http://ecdc.europa.eu/en/publications/Publications/20121130-Annual-HIV-Surveillance-Report.pdf

[2] ECDC/WHO/Europe (2011) HIV/AIDS Surveillance in Europe, 2011.

(a) http://ecdc.europa.eu/en/publications/Publications/20121130-Annual-HIV-Surveillance-Report.pdf

(b) http://www.euro.who.int/ data/assets/pdf file/0006/154554/e96000.pdf

[3] Likatavicius, G. and Van de Laar, M. (2012) HIV and AIDS in the European Union, 2011. Eurosurveillance, 17, pii= 20329. http://www.eurosurveillance.org/ViewArticle.aspx?ArticleId=20329

[4] van de Laar, M.J. (2009) HIV/AIDS and Other STI in Men Who Have Sex with Men-A Continuous Challenge for Public Health. Eurosurveillance, 14, pii=19423. Available Online: “A Five-Year Plan to Combat HIV in the EU and Its Neighbouring Countries”. http://www.eurosurveillance.org/ViewArticle.aspx?ArticleId=19423

[5] European Centre for Disease Prevention Control, TECHNICAL REPORT (2013) A Comprehensive Approach to HIV/STI Prevention in the Context of Sexual Health in the EU/EE.

http://ecdc.europa.eu/en/publications/Publications/HVI-STI-prevention-comprehensive-approach-in-the-context-of-sex ual-health-EU-EEA.pdf

[6] European Centre for Disease Prevention and Control (2013) The EMIS Network, EMIS 2010 The European Men-Who-Have-Sex-with-Men Internet Survey. Findings from 38 Countries. http://ecdc.europa.eu/en/publications/Publications/EMIS-2010-european-men-who-have-sex-with-men-survey.pdf

[7] Frentz, D., Wensing, A.M.J., Albert, J., Paraskevis, D., Abecasis, A.B., Hamouda, O., Jørgensen, L.B., Kücherer, C., Struck, D., Schmit, J.C., Åsjö, B., Balotta, C., Beshkov, D., Camacho, R.J., Clotet, B., Coughlan, S., De Wit, S., Griskevicius, A., Grossman, Z., Horban, A., Kolupajeva, T., Korn, K., Kostrikis, L.G., Liitsola, K., Linka, M., Nielsen, C., Otelea, D., Paredes, R., Poljak, M., Puchhammer-Stöck, E., Sönnerborg, A., Stanekova, D., Stanojevic, M., Vandamme, A.M., Boucher, C.A.B., Van de Vijver, D.A.M.C. and SPREAD Programme (2013) Limited Cross-Border Infections in Patients Newly Diagnosed with HIV in Europe. Retrovirology, 10, 36. http://dx.doi.org/10.1186/1742-4690-10-36

[8] Centers for Disease Control and Prevention, USA (2013) HIV in the United States: At a Glance. http://www.cdc.gov/hiv/pdf/statistics_basics_factsheet.pdf http://www.cdc.gov/hiv/resources/factsheets/us.htm

[9] Paz-Bailey, G., Hall, H.I., Wolitski, R.J., Prejean, J., Van Handel, M.M., Le, B., LaFlam, M., Koenig, L.J., Mendoza, M.C.B., Rose, C. and Valleroy, L.A. (2013) HIV Testing and Risk Behaviours among Gay, Bisexual, and Other Men Who Have Sex with Men-United States. Morbidity and Mortality Weekly Report (MMWR), 62, 958-962.

[10] Vu St., L., Velter, A., Meyer, L., Peytavin, G., Guinard, J., Pillonel, J., Barin, F. and Semaille, C. (2012) Incidence de l'infection par le VIH dans un échantillond'hummesayant des relations sexuelles avec des homes á Paris. Bulletin épidémiologique hebdomadaire, December 1, No. 46-47, 537-540. (article in French with an English abstract)

[11] Health Protection Agency/HPA (2012) HIV in the United Kingdom: 2012 Overview. http://www.hpa.org.uk/webc/HPAwebFile/HPAweb_C/1317137200234.

[12] RKI (2013) Weiterführende Analysen zur HIV-Inzidenz-und-Prävalenzschätzung 2012. Epidemiologisches Bulletin, 45, 457-464. (article in German) 
[13] Kerr, L.R., Mota, R.S., Kendall, C., Pinho Ade, A., Mello, M.B., Guimarães, M.D., Dourado, I., de Brito, A.M., Benzaken, A., McFarland, W., Rutherford, G. and HIVMSM Surveillance Group (2013) HIV among MSM in a Large Middle-Income Country. AIDS, 27, 427-435. http://dx.doi.org/10.1097/QAD.0b013e32835ad504

[14] Beyrer, C., Baral, S.D., van Griensven, F., Goodreau, S.M., Chariyalertsak, S., Wirtz, A.L. and Brookmeyer, R. (2012) Global Epidemiology of HIV Infection in Men Who Have Sex with Men. Lancet, 380, 367-377. http://dx.doi.org/10.1016/S0140-6736(12)60821-6

[15] De Cock, K.M., Jaffe, H.W. and Curran, J.W. (2012) The Evolving Epidemiology of HIV/AIDS. AIDS, 26, 1205-1213. http://dx.doi.org/10.1097/QAD.0b013e328354622a

[16] UNAIDS (2012) Report on the Global AIDS Epidemic. http://www.unaids.org/en/media/unaids/contentassets/documents/epidemiology/2012/gr2012/20121120_unaids_global _report_2012_with_annexes_en.pdf

[17] UNAIDS (2012) Epidemiological Factsheet, China. http://www.unaids.org/en/regionscountries/countries/china/

[18] Wu, Z., Wang, Y., Detels, R. and Rotheram-Borus, M.J. (2010) China AIDS Policy Implementation: Reversing the HIV/AIDS Epidemic by 2015. International Journal of Epidemiology, 39, ii1-ii3. http://dx.doi.org/10.1093/ije/dyq220

[19] Whitmore, S.K., Kann, L., Prejean, J., Koenig, L.J., Branson, B.M., Hall, H.I., Fasula, A.M., Tracey, A., Mermin, J. and Valleroy, L.A. (2012) Vital Signs: HIV Infection, Testing, and Risk Behaviours among Youths-United States. Morbidity and Mortality Weekly Report (MMWR), 61, 971-976.

http://www.cdc.gov/mmwr/preview/mmwrhtml/mm6147a5.htm?s_cid=mm6147a5_w

[20] Baggaley, R.F., White, R.G. and Boily, M.C. (2010) HIV Transmission Risk through Anal Intercourse: Systematic Review, Meta-Analysis and Implications for HIV Prevention. International Journal of Epidemiology, 39, 1048-1063. http://dx.doi.org/10.1093/ije/dyq057

[21] Executive Summary (2012) HIV in Men Who Have Sex with Men. The Lancet, 380. http://www.thelancet.com/series/hiv-in-men-who-have-sex-with-men.

[22] Fenton, K. (2013) The Resurgent Global HIV Epidemic among Men Who Have Sex with Men. BHIVA Autumn Conference 2013. London, 14-15 November 2013.

http://www.bhiva.org/documents/Conferences/Autumn2013/presentations/131114/KevinFenton.pdf.

[23] Beyrer, C., Sullivan, P., Sanchez, J., Barala, S.D., Collins, C., Wirtza, A.L., Altman, D., Trapence, G. and Mayer, K. (2013) The Increase in Global HIV Epidemics in MSM. AIDS, 27, 2665-2678. http://dx.doi.org/10.1097/01.aids.0000432449.30239.fe

[24] Klein, H. (2009) Sexual Orientation, Drug Use Preference during Sex, and HIV Risk Practices and Preferences among Men Who Specifically Seek Unprotected Sex Partners via the Internet. International Journal of Environmental Research and Public Health, 6, 1620-1632. http://dx.doi.org/10.3390/ijerph6051620

[25] Muessig, K.E., Smith, M.K., Powers, K.A., Lo, Y.R., Burns, D.N., Grulich, A.E., Phillips, A.N. and Cohen, M.S. (2012) Does ART Prevent HIV Transmission among MSM? AIDS, 26, 2267-2273. http://dx.doi.org/10.1097/QAD.0b013e328355713d

[26] Dodds, J.P., Mercey, D.E., Parry, J.V. and Johnson, A.M. (2004) Increasing Risk Behaviour and High Levels of Undiagnosed HIV Infection in a Community Sample of Homosexual Men. Sexually Transmitted Infections, 80, $236-240$. http://dx.doi.org/10.1136/sti.2003.007286

[27] Rosser, B.R., Oakes, J.M., Horvath, K.J., Konstan, J.A., Danilenko, G.P. and Peterson, J.L. (2009) HIV Sexual Risk Behaviour by Men Who Use the Internet to Seek Sex with Men: Results of the Men's INTernet Sex Study-II (MINTS-II). AIDS and Behavior, 13, 488-498. http://dx.doi.org/10.1007/s10461-009-9524-3

[28] AVERT International HIV \& AIDS Charity (2012) HIV \& AIDS in Western Central Europe, Preventing HIV Transmission among Men Who Have Sex with Men (MSM). http://www.avert.org/hiv-aids-western-central-europe.htm

[29] European Centre for Disease Prevention and Control, Stockholm (2013) STI and HIV Prevention in Men Who Have Sex with Men in Europe.

http://www.ecdc.europa.eu/en/publications/Publications/STI-HIV-prevention-MSM-in-Europe-21-Feb-2013.pdf

[30] Averhoff, F.M., Glass, N. and Holtzman, D. (2012) Global Burden of Hepatitis C: Considerations for Healthcare Providers in the United States. Clinical Infectious Diseases, 55, S10-S15. http://dx.doi.org/10.1093/cid/cis361

[31] Terrault, N.A., Dodge, J.L., Murphy, E.L., Tavis, J.E., Kiss, A., Levin, T.R., Gish, R.G., Busch, M.P., Reingold, A.L. and Alter, M.J. (2013) Sexual Transmission of Hepatitis C Virus among Monogamous Heterosexual Couples: The HCV Partners Study. Hepatology, 57, 881-889.

[32] CDC/USA (2010) Hepatitis C, General Information, Can Hepatitis C Be Spread through Sex? http://www.cdc.gov/hepatitis/hcv/pdfs/hepcgeneralfactsheet.pdf

[33] Pouget, E.R., Hagan, H. and Des Jarlais, D.C. (2012) Meta-Analysis of Hepatitis C Seroconversion in Relation to 
Shared Syringes and Drug Preparation Equipment. Addiction, 107, 1057-1065.

http://dx.doi.org/10.1111/j.1360-0443.2011.03765.X

[34] Hauri, A.M., Armstrong, G.L. and Hutin, Y.J. (2004) The Global Burden of Disease Attributable to Contaminated Injections Given in Health Care Settings. International Journal of STD \& AIDS, 15, 7-16. http://dx.doi.org/10.1258/095646204322637182

[35] Kirby, T. and Thornber-Dunwell, M. (2013) High-Risk Drug Practices Tighten Grip on London Gay Scene. Lancet, 381, 101-102.

[36] Positivrat, Schweiz: POSITIV: E-Mail-Newsletter of the Aids-HilfeSchweiz and Positivrats. (2012) Lebenmit HIV/Aids. [Article in German] http://www.positivrat.ch/de/aktuell/problematisch-hepatitis-c/

[37] Schmidt, A.J., Rockstroh, J.K., Vogel, M., An der Heiden, M., Baillot, A., Krznaric, I. and Radun, D. (2011) Trouble with Bleeding: Risk Factors for Acute Hepatitis C among HIV-Positive Gay Men from Germany-A Case-Control Study. PLoS ONE, 6, Article ID: e17781. http://dx.doi.org/10.1371/journal.pone.0017781

[38] Ciesek, S., Friesland, M., Steinmann, J., Becker, B., Wedemeyer, H., Manns, M.P., Steinmann, J., Pietschmann, T. and Steinmann, E. (2010) How Stable Is the Hepatitis C Virus (HCV)? Environmental Stability of HCV and Its Susceptibility to Chemical Biocides. Journal of Infectious Diseases, 201, 1859-1866. http://dx.doi.org/10.1086/652803

[39] Doerrbecker, J., Behrendt, P., Mateu-Gelabert, P., Ciesek, S., Riebesehl, N., Wilhelm, C., Steinmann, J., Pietschmann, T. and Steinmann, E. (2013) Transmission of Hepatitis C Virus among People Who Inject Drugs: Viral Stability and Association with Drug Preparation Equipment. Journal of Infectious Diseases, 207, 281-287. http://dx.doi.org/10.1093/infdis/jis677

[40] Paintsil, E., Binka, M., Patel, A., Lindenbach, B.D. and Heimer, R. (2013) Hepatitis C Virus Maintains Infectivity for Weeks after Drying on Inanimate Surfaces at Room Temperature: Implications for the Risk of Transmission. Journal of Infectious Diseases, 209, 1205-1211. http://www.ncbi.nlm.nih.gov/pubmed/24273176

[41] Urbanus, A.T., van de Laar, T.J., Stolte, I.G., Schinkel, J., Heijman, T., Coutinho, R.A. and Prins, M. (2009) Hepatitis C Virus Infections among HIV-Infected Men Who Have Sex with Men: An Expanding Epidemic. AIDS, 23, F1-F7. http://dx.doi.org/10.1097/QAD.0b013e32832e5631

[42] Bradshaw, D., Matthews, G. and Danta, M. (2013) Sexually Transmitted Hepatitis C Infection: The New Epidemic in MSM? Current Opinion in Infectious Diseases, 26, 66-72.

http://www.docguide.com/sexually-transmitted-hepatitis-c-infection-new-epidemic-msm?hash=9e0fd208\&eid=30228 \&alrhash=38d41c-a83b1aff4e901870b3840531112cadd9

[43] Giuliani, M., Nosotti, L., Latini, A., Mirisola, C., Pimpinelli, F., Volpi, S., Ensoli, F., Impara, G. and Palamara, G. (2011) Hepatitis C Virus Infection among Non-IDU HIV-Infected and Uninfected Men Who Have Sex with Men. Mediterranean Journal of Hematology and Infectious Diseases, 3, Article ID: e2011058. http://dx.doi.org/10.4084/mjhid.2011.058

[44] Merchante, N., Merino, E., López-Aldeguer, J., Jover, F., Delgado-Fernández, M., Galindo, M.J., Ortega, E., Rivero, A., Mínguez, C., Romero-Palacios, A., Padilla, S., Márquez-Solero, M., Amador, C., Ríos-Villegas, M.J., Téllez, F., Portilla, J. and Pineda, J.A. (2013) Increasing Incidence of Hepatocellular Carcinoma in HIV-Infected Patients in Spain. Clinical Infectious Diseases, 56, 143-150. http://dx.doi.org/10.1093/cid/cis777

[45] Ioannou, G.N., Bryson, C.L., Weiss, N.S., Miller, R., Scott, J.D. and Boyko, E.J. (2013) The Prevalence of Cirrhosis and Hepatocellular Carcinoma in Patients with Human Immunodeficiency Virus Infection. Hepatology, 57, $249-257$. http://dx.doi.org/10.1002/hep.25800

[46] Yaphe, S., Bozinoff, N., Kyle, R., Shivkumar, S., Pant Pai, N. and Klein, M. (2012) Incidence of Acute Hepatitis C Virus Infection among Men Who Have Sex with Men with and without HIV Infection: A Systematic Review. Sexually Transmitted Diseases, 88, 558-564. http://dx.doi.org/10.1136/sextrans-2012-050566

[47] van de Laar, T.J.W., Paxton, W.A., Zorgdrager, F., Cornelissen, M. and de Vries, H.J.C. (2011) Sexual Transmission of Hepatitis C Virus in Human Immunodeficiency Virus-Negative Men Who Have Sex with Men: A Series of Case Reports. Sexually Transmitted Diseases, 38, 102-104. http://dx.doi.org/10.1097/OLQ.0b013e3181ec9de5

[48] Matthews, G.V., Pham, S.T., Hellard, M., Grebely, J., Zhang, L., Oon, A., Marks, P., van Beek, I., Rawlinson, W., Kaldor, J.M., Lloyd, A., Dore, G.J., White, P.A. and on Behalf of the ATAHC Study Group (2011) Patterns and Characteristics of Hepatitis C Transmission Clusters among HIV-Positive and HIV-Negative Individuals in the Australian Trial in Acute Hepatitis C. Clinical Infectious Diseases, 52, 803-811. http://dx.doi.org/10.1093/cid/ciq200

[49] Kim, A.Y., Onofrey, S. and Church, D.R. (2013) An Epidemiologic Update on Hepatitis C Infection in Persons Living With or at Risk of HIV Infection. Journal of Infectious Diseases, 207, S1-S6. http://dx.doi.org/10.1093/infdis/jis927

[50] Scott, C., Day, S., Low, E., Sullivan, A., Atkins, M. and Asboe, D. (2010) Unselected Hepatitis C Screening of Men 
Who Have Sex with Men Attending Sexual Health Clinics. Journal of Infection, 60, 351-353. http://dx.doi.org/10.1016/j.jinf.2010.01.013

[51] Centers for Disease Control and Prevention (CDC) (2011) Sexual Transmission of Hepatitis C Virus among HIV-Infected Men Who Have Sex with Men-New York City, 2005-2010. Morbidity and Mortality Weekly Report (MMWR), 60, 945-950.

[52] Sulkowski, M.S. (2012) Hepatitis C Virus-Human Immunodeficiency Virus Coinfection. Liver International, 32, 129- 134. http://dx.doi.org/10.1111/j.1478-3231.2011.02719.x

[53] Martin, T.C., Martin, N.K., Hickman, M., Vickerman, P., Page, E.E., Everett, R., Gazzard, B.G. and Nelson, M. (2013) HCV Reinfection Incidence and Treatment Outcome among HIV-Positive MSM. AIDS, 27, 2551-2557.

[54] Ingiliz, P., Martin, T.C., Boesecke, C., Mauss, S., Payer, B.A., Mandorfer, M., Baumgarten, A., Stellbrink, H.J., Bhagani, S., Rockstroh, J.K., Nelson, M. and the NEAT Study Groupet (2013) Substantial Rates of Acute Hepatitis C Reinfection in European HIV-Positive Patients. 14th European AIDS Conference, Brussels, Abstract PS9/1. http://www.professionalabstracts.com/eacs2013/planner/index.php?go=abstract\&action=abstract show\&absno=920\&

[55] Chou, R., Cottrell, E.B., Wasson, N., Rahman, B. and Guise, J.M. (2013) Screening for Hepatitis C Virus Infection in Adults: A Systematic Review for the U.S. Preventive Services Task Force. Annals of Internal Medicine, 158, 101-108. http://annals.org/article.aspx?articleid=1458679\&atab=7 http://dx.doi.org/10.1097/QAD.0b013e32836381cc

[56] Schreuder, I., van der Sande, M.A.B., de Wit, M., Bongaerts, M., Boucher, C.A.B., Croes, E.A. and van Veen, M.G. (2010) Seroprevalence of HIV, Hepatitis B, and Hepatitis C among Opioid Drug Users on Methadone Treatment in the Netherlands. Harm Reduction Journal, 7, 25. http://dx.doi.org/10.1186/1477-7517-7-25 http://www.harmreductionjournal.com/content/7/1/25

[57] Tran, T.T. (2013) Hepatitis B Virus Coinfection: HIV and Hepatitis C and D Viruses, Hepatitis B Virus and HIV Coinfection. Clinical Care Options in Practice. http://www.clinicaloptions.com/inPractice/Hepatology/Hepatology/ch5_Hep_B_Spec_Populations/Pages/Page\%202.as px

[58] van Houdt, R., Bruisten, S.M., Speksnijder, A.G. and Prins, M. (2012) Unexpectedly High Proportion of Drug Users and Men Having Sex with Men Who Develop Chronic Hepatitis B Infection. Journal of Hepatology, 57, 529-533. http://dx.doi.org/10.1016/j.jhep.2012.04.030

[59] Thio, C.L., Smeaton, L., Saulynas, M., Hwang, H., Saravan, S., Kulkarni, S., Hakim, J., Nyirenda, M., Iqbal, H.S., Lalloo, U.G., Mehta, A.S., Hollabaugh, K., Campbell, T.B., Lockman, S. and Currier, J.S. (2013) Characterization of HIV-HBV Coinfection in a Multinational HIV-Infected Cohort. AIDS, 27, 191-201. http://dx.doi.org/10.1097/QAD.0b013e32835a9984

[60] European Centre for Disease Prevention and Control (2013) STI and HIV Prevention in Men Who Have Sex with Men in Europe. ECDC, Stockholm. http://ecdc.europa.eu/en/publications/publications/sti-hiv-prevention-msm-in-europe-21-feb-2013.pdf

[61] Savage, E., Hughes, G., Ison, C. and Lowndes, C.M. (2009) European Surveillance of Sexually Transmitted Infections Network, Syphilis and Gonorrhoea in Men Who Have Sex with Men: A European Overview. Eurosurveillance, 14, pii=19417. http://www.eurosurveillance.org/ViewArticle.aspx?ArticleId=19417

[62] Nanín, J.E., Bimbi, D.S., Grov, C. and Parsons, J.T. (2009) Community Reactions to a Syphilis Prevention Campaign for Gay and Bisexual Men in Los Angeles County. Journal of Sex Research, 46, 525-534. http://dx.doi.org/10.1080/00224490902829590

[63] Jin, F., Prestage, G.P., Zablotska, I., Rawstorne, P., Imrie, J., Kippax, S.C., Donovan, B., Templeton, D.J., Kaldor, J.M. and Grulich, A.E. (2009) High Incidence of Syphilis in HIV-Positive Homosexual Men: Data from Two CommunityBased Cohort Studies. Sexual Health, 6, 281-284. http://dx.doi.org/10.1071/SH09060

[64] Tucker, J.D., Yin, Y.P., Wang, B., Chen, X.S. and Cohen, M.S. (2011) An Expanding Syphilis Epidemic in China: Epidemiology, Behavioural Risk and Control Strategies with a Focus on Low-Tier Female Sex Workers and Men Who Have Sex with Men. Sexually Transmitted Diseases, 87, ii16-ii18. http://dx.doi.org/10.1136/sti.2010.048314

[65] Mooij, S.H., Boot, H.J., Speksnijder, A.G., Stolte, I.G., Meijer, C.J., Snijders, P.J., Verhagen, D.W., King, A.J., de Vries, H.J., Quint, W.G., van der Sande, M.A. and van der Loeff, M.F.S. (2013) Oral Human Papillomavirus Infection in HIV-Negative and HIV-Infected Men Who Have Sex with Men. The HIV \& HPV in MSM (H2M) Study. AIDS, 27, 2117-2128. http://dx.doi.org/10.1097/QAD.0b013e328362395c

[66] Houlihan, C.F., Larke, N.L., Watson-Jones, D., Smith-McCune, K.K., Shiboski, S., Gravitt, P.E., Smith, J.S., Kuhn, L., Wang, C. and Hayes, R. (2012) Human Papillomavirus Infection and Increased Risk of HIV Acquisition. A Systematic Review and Meta-Analysis. AIDS, 26, 2211-2222. http://dx.doi.org/10.1097/QAD.0b013e328358d908

[67] Van Aar, F., Mooij, S.H., Van Der Sande, M.A., Speksnijder, A.G., Stolte, I.G., Meijer, C.J., Verhagen, D.W., King, 
A.J., De Vries, H.J. and Van Der Loeff, M.F. (2013) Anal and Penile High-Risk Human Papillomavirus Prevalence in HIV-Negative and HIV-Infected MSM. AIDS, 27, 2921-2931. http://dx.doi.org/10.1097/01.aids.0000432541.67409.3c

[68] Sahasrabuddhe, V.V., Castle, P.E., Follansbee, S., Borgonovo, S., Tokugawa, D., Schwartz, L.M., Lorey, T.S., LaMere, B.J., Gage, J.C., Fetterman, B., Boyle, S., Sadorra, M., Tang, S.D., Darragh, T.M. and Wentzensen, N. (2013) Human Papillomavirus Genotype Attribution and Estimation of Preventable Fraction of Anal Intraepithelial Neoplasia Cases among HIV-Infected Men Who Have Sex with Men. Journal of Infectious Diseases, 207, 392-401. http://dx.doi.org/10.1093/infdis/jis694

[69] Quinn, R., Salvatierra, J., Solari, V., Calderon, M., Ton, T.G. and Zunt, J.R. (2012) Human Papillomavirus Infection in Men Who Have Sex with Men in Lima, Peru. AIDS Research and Human Retroviruses, 28, 1734-1738. http://dx.doi.org/10.1089/aid.2011.0307

[70] Shiramizu, B., Liang, C.Y., Agsalda-Garcia, M., Nagata, I., Milne, C., Zhu, X., Killeen, J., Berry, J.M. and Goodman, M.T. (2013) Presence of High-Risk Human Papillomavirus Genotype and Human Immunodeficiency Virus DNA in Anal High-Grade and Low-Grade Squamous Intraepithelial Lesions. AIDS Research and Human Retroviruses, 29, 178-181. http://online.liebertpub.com/doi/abs/10.1089/aid.2012.0136 http://dx.doi.org/10.1089/aid.2012.0136

[71] Read, T.R.H., Hocking, J.S., Vodstrcil, L.A., Tabrizi, S.N., McCullough, M.J., Grulich, A.E., Garland, S.M., Bradshaw, C.S., Chen, M.Y. and Fairley, C.K. (2012) Oral Human Papillomavirus in Men Having Sex with Men: Risk-Factors and Sampling. PLoS ONE, 7, Article ID: e49324. http://dx.doi.org/10.1371/journal.pone.0049324

[72] European Centre for Disease Prevention and Control (2012) Introduction of HPV Vaccines in EU Countries-An Update. ECDC, Stockholm. http://ecdc.europa.eu/en/publications/publications/20120905_gui_hpv_vaccine_update.pdf

[73] Gianella, S., Morris, S.R., Anderson, C., Spina, C.A., Vargas, M.V., Young, J.A., Richman, D.D., Little, S.J. and Smith, D.M. (2013) Herpes Viruses and HIV-1 Drug Resistance Mutations Influence the Virologic and Immunologic Milieu of the Male Genital Tract. AIDS, 27, 39-47. http://dx.doi.org/10.1097/QAD.0b013e3283573305

[74] Tobian, A.A. and Quinn, T.C. (2009) Herpes Simplex Virus Type 2 and Syphilis Infections with HIV: An Evolving Synergy in Transmission and Prevention. Current Opinion in HIV \& AIDS, 4, 294-299. http://dx.doi.org/10.1097/COH.0b013e32832c1881

[75] Pott, E. (2007) AIDS Prevention in GERMANY (Article in German, English Abstract). Bundesgesundheitsblatt-Gesundheitsforschung-Gesundheitsschutz, 50, 422-431. http://dx.doi.org/10.1007/s00103-007-0185-y

[76] European Centre for Disease and Prevention Control, The EMIS Network (2013) EMIS 2010: The European MenWho-Have-Sex-with-Men Internet Survey. Findings from 38 Countries. ECDC, Stockholm. http://www.ecdc.europa.eu/en/publications/Publications/EMIS-2010-european-men-who-have-sex-with-men-survey.pd $\underline{\mathrm{f}}$

[77] King-Spooner, S. (1999) HIV Prevention and the Positive Population. International Journal of STD \& AIDS, 10, 141-150. Further Comments in AIDSmap: http://www.aidsmap.com/Prevention-programmes-for-HIV-positive-people/page/1768336/

[78] Piguet, V. and Steinann, R.M. (2007) The Interaction of HIV with Dendritic Cells: Outcomes and Pathways. Trends in Immunology, 28, 503-510. http://dx.doi.org/10.1016/j.it.2007.07.010

[79] Jin, F., Prestage, G.P., Templeton, D.J., Poynten, I.M., Donovan, B., Zablotska, I., Kippax, S.C., Mindel, A. and Grulich, A.E. (2012) The Impact of Seroadaptive Behaviours on Sexually Transmissible Infections in HIV-Negative Homosexual Men in Sydney, Australia. Sexually Transmitted Diseases, 39, 191-194. http://dx.doi.org/10.1097/OLQ.0b013e3182401a2f

[80] Beck, A., McNally, I. and Petrak, J. (2003) Psychosocial Predictors of HIV/STI Risk Behaviours in a Sample of Homosexual Men. Sexually Transmitted Diseases, 79, 142-146. http://dx.doi.org/10.1136/sti.79.2.142

[81] Bradley, M.V., Remien, R.H. and Dolezal, C. (2008) Depression Symptoms and Sexual HIV Risk Behaviour amongSerodiscordant Couples. Psychosomatic Medicine, 70, 186-191. http://dx.doi.org/10.1097/PSY.0b013e3181642a1c

[82] Carvalho, F.T., Gonçalves, T.R., Faria, E.R., Shoveller, J.A., Piccinini, C.A., Ramos, M.C. and Medeiros, L.R. (2011) Behavioural Interventions to Promote Condom Use among Women Living with HIV. Cochrane Database of Systematic Reviews, 7, Article ID: CD007844d. http://dx.doi.org/10.1002/14651858.CD007844.pub2

[83] Goetz, M.B., Hoang, T., Henry, S.R., Knapp, H., Anaya, H.D., Gifford, A.L., Asch, S.M., QUERI-HIV/Hepatitis Program (2009) Evaluation of the Sustainability of an Intervention to Increase HIV Testing. Journal of General Internal Medicine, 24, 1275-1280. http://dx.doi.org/10.1007/s11606-009-1120-8

[84] The Healthy Living Project Team (2007) Effects of a Behavioural Intervention to Reduce Risk of Transmission among People Living with HIV: The Healthy Living Project Randomized Controlled Study. JAIDS Journal of Acquired Immune Deficiency Syndromes, 44, 213-221. http://dx.doi.org/10.1097/QAI.0b013e31802c0cae 
[85] Johnson, W.D., Diaz, R.M., Flanders, W.D., Goodman, M., Hill, A.N., Holtgrave, D., Malow, R. and McClellan, W.M. (2008) Behavioural Interventions to Reduce Risk for Sexual Transmission of HIV among Men Who Have Sex with Men. Cochrane Database of Systematic Reviews, 3, Article ID: CD001230. http://dx.doi.org/10.1002/14651858.CD001230.pub2

[86] Berg, R. (2009) The Effectiveness of Behavioural and Psychological HIV/STI Prevention Interventions for MSM in Europe: A Systematic Review. Eurosurveillance, 14, pii=19430. http://www.eurosurveillance.org/ViewArticle.aspx?ArticleId=19430

[87] Durantini, M.R., Albarracin, D., Mitchell, A.L., Earl, A.N. and Gillette, J.C. (2006) Conceptualizing the Influence of Social Agents of Behaviour Change: A Meta-Analysis of the Effectiveness of HIV-Prevention Interventionists for Different Groups. Psychological Bulletin, 132, 212-248. http://dx.doi.org/10.1037/0033-2909.132.2.212

[88] van Griensven, F., de Lind van Wijngaarden, J.W., Baral, S. and Grulich, A. (2009) The Global Epidemic of HIV Infection among Men Who Have Sex with Men. Current Opinion in HIV \& AIDS, 4, 300-307. http://dx.doi.org/10.1097/COH.0b013e32832c3bb3

[89] UNAIDS (2013) Global Report-UNAIDS Report on the Global AIDS Epidemic 2013. http://www.unaids.org/en/dataanalysis/knowyourepidemic/

[90] Editorial/UNAIDS (2013) New HIV Infections among Couples in Africa Pose Huge Challenge. http://news.xinhuanet.com/english/health/2013-07/12/c 132533603.htm.

[91] Editorial (2011) A Strategic Revolution in HIV and Global Health. Lancet, 377, 2055. http://dx.doi.org/10.1016/S0140-6736(11)60901-X

[92] Sidibé, M., Piot, P. and Dybul, M. (2012) AIDS Is Not Over. Lancet, 380, 2058-2060. http://dx.doi.org/10.1016/S0140-6736(12)62088-1

[93] (a) WHO (2011) The Global Health Sector Strategy on HIV/AIDS 2011-2015. http://whqlibdoc.who.int/publications/2011/9789241501651_eng.pdf (b) WHO (2011) A New Healthsector Agenda for HIV/AIDS, Global Health Sector Strategy on HIV/AIDS, 20112015. http://www.who.int/hiv/pub/advocacy_brochure/en/

[94] Stall, R. (2007) Efforts to Prevent HIV Infection That Target People Living with HIV/AIDS: What Works? Clinical Infectious Diseases, 45, S308-S312. http://dx.doi.org/10.1086/522555

[95] European Centre for Disease Prevention and Control (2013) Public Health Benefits of Partner Notification for Sexually Transmitted Infections and HIV. ECDC, Stockholm. http://www.ecdc.europa.eu/en/publications/Publications/Partner-notification-for-HIV-STI-June-2013.pdf

[96] Rayment, M. (2013) Partner Notification Highly Effective at Finding New HIV Cases, but a Third Who Could Be Tested Are Missed.

http://www.aidsmap.com/Partner-notification-highly-effective-at-finding-new-HIV-cases-but-a-third-who-could-be-tes ted-are-missed/page/2804912/ http://www.bhiva.org/Presentations131114.aspx

[97] CDC, USA (2013) High-Impact HIV Prevention: CDC’s Approach to Reducing HIV Infections in the United States. http://www.cdc.gov/hiv/strategy/hihp/report/

[98] Morris, S.R. and Little, S.J. (2011) MSM: Resurgent Epidemics. Current opinion in HIV and AIDS, 6, 326-332.

[99] Koblin, B.A., Chesney, M.A., Husnik, M.J., Bozeman, S., Celum, C.L., Buchbinder, S., Mayer, K., McKirnan, D., Judson, F.N., Huang, Y., Coates, T.J. and the EXPLORE Study Team (2003) High-Risk Behaviours among Men Who Have Sex with Men in 6 US Cities: Baseline Data from the EXPLORE Study. American Journal of Public Health, 93, 926-932. http://dx.doi.org/10.2105/AJPH.93.6.926

[100] Laga, M., Rugg, D., Peersman, G. and Ainsworth, M. (2012) Evaluation HIV Prevention Effectiveness: The Perfect as the Enemy of the Good. AIDS, 26, 779-783. http://dx.doi.org/10.1097/QAD.0b013e328351e7fb

[101] Fauci, A. (2011) HIV Turns 30: Reflections from Dr. Anthony Fauci of NIAID. Interview. http://www.medscape.com/viewarticle/743671

[102] Schwartländer, B., Stover, J., Hallett, T., Atun, R., Avila, C., Gouws, E., Bartos, M., Ghys, P.D., Opuni, M., Barr, D., Alsallaq, R., Bollinger, L., de Freitas, M., Garnett, G., Holmes, C., Legins, K., Pillay, Y., Stanciole, A.E., McClure, C., Hirnschall, G., Laga, M. and Padian, N. (2011) Towards an Improved Investment Approach for an Effective Response to HIV/AIDS. Lancet, 377, 2031-2041. http://dx.doi.org/10.1016/S0140-6736(11)60702-2

[103] Frieden, T.R., Das-Douglas, M., Kellerman, S.E. and Henning, K.J. (2005) Applying Public Health Principles to the HIV Epidemic. New England Journal of Medicine, 353, 2397-2402. http://dx.doi.org/10.1056/NEJMsb053133

[104] Montaner, J.S.G. (2011) Treatment as Prevention—A Double Hat-Trick. Lancet, 378, 208-209. http://dx.doi.org/10.1016/S0140-6736(11)60821-0 
[105] Miller, W.C., Powers, K.A., Smith, M.K. and Cohen, M.S. (2013) Community Viral Load as a Measure for Assessment of HIV Treatment as Prevention. Lancet Infectious Diseases, 13, 459-464. http://dx.doi.org/10.1016/S1473-3099(12)70314-6

[106] Vernazza, P., Hirschel, B., Bernasconi, E. and Flepp, M. (2008) HIV-Positive Individuals Not Suffering from Any Other STD and Adhering to an Effective Antiretroviral Treatment Do Not Transmit HIV Sexually. Schweizerische Ärztezeitung/Bulletin des médecins suisses. Bollettino dei medici svizzeri, 89, 165-169. http://www.aidslaw.ca/EN/lawyers-kit/documents/8.Vernazza2008.pdf

[107] Politch, J.A., Mayer, K.H., Welles, S.L., O’Brien, W.X., Xu, C., Bowman, F.P. and Anderson, D.J. (2012) Highly Active Antiretroviral Therapy Does Not Completely Suppress HIV in Semen of Sexually-Active HIV-Infected Men Who Have Sex with Men. AIDS, 26, 1535-1543. http://dx.doi.org/10.1097/QAD.0b013e328353b11b

[108] Lambert-Niclot, S., Tubiana, R., Beaudoux, C., Lefebvre, G., Caby, F., Bonmarchand, M., Naouri, M., Schubert, B., Dommergues, M., Calvez, V., Flandre, P., Poirot, C. and Marcelin, A.G. (2012) Detection of HIV-1 RNA in Seminal Plasma Samples from Treated Patients with Undetectable HIV-1 RNA in Blood Plasma in a 2002-2011 Survey. AIDS, 26, 971-975. http://dx.doi.org/10.1097/QAD.0b013e328352ae09

[109] Fiscus, S.A., Cu-Uvin, S., Eshete, A.T., Hughes, M.D., Bao, Y., Hosseinipour, M., Grinsztejn, B., Badal-Faesen, S., Dragavon, J., Coombs, R.W., Braun, K., Moran, L., Hakim, J., Flanigan, T., Kumarasamy, N., Campbell, T.B. for the A5185s Team (2013) Changes in HIV-1 Subtypes B and C Genital Tract RNA in Women and Men after Initiation of Antiretroviral Therapy. Clinical Infectious Diseases, 57, 290-297. http://dx.doi.org/10.1093/cid/cit195

[110] Kalichman, S.C., Grebler, T., Amaral, C.M., McKerey, M., White, D., Kalichman, M.O., Cherry, C. and Eaton, L. (2013) Assumed Infectiousness, Treatment Adherence and Sexual Behaviours: Applying the Swiss Statement on Infectiousness to HIV-Positive Alcohol Drinkers. HIV Medicine, 14, 263-272.

[111] Tanser, F., Bärnighausen, T., Grapsa, E., Zaidi, J. and Newell, M.L. (2013) High Coverage of ART Associated with Decline in Risk of HIV Acquisition in Rural KwaZulu-Natal, South Africa. Science, 339, 966-971. http://dx.doi.org/10.1126/science.1228160

[112] Krentz, H.B. and Gill, M.J. (2013) The Effect of Churn on 'Community Viral Load' (CVL) in a Well-Defined Regional Population. JAIDS Journal of Acquired Immune Deficiency Syndromes, 64, 190-196. http://dx.doi.org/10.1097/QAI.0b013e31829cef18

[113] Wilson, D.P. (2012) HIV Treatment as Prevention: Natural Experiments Highlight Limits of Antiretroviral Treatment as HIV Prevention. PLoS Medicine, 9, Article ID: e1001231. http://dx.doi.org/10.1371/journal.pmed.1001231

[114] World Health Organization (2013) Consolidated Guidelines on the Use of Antiretroviral Drugs for Treating and Preventing HIV Infection. WHO 2013. http://www.who.int/hiv/pub/guidelines/arv2013/download/en/index.htm

[115] Sabin, C.A., Cooper, D.A., Collins, S. and Schechter, M. (2013) Rating Evidence in Treatment Guidelines: A Case Example of When to Initiate Combination Antiretroviral Therapy (cART) in HIV-Positive Asymptomatic Persons. AIDS, 27, 1839-1846. http://dx.doi.org/10.1097/QAD.0b013e328360d546

[116] Hofstra, M., Sauvageot, N., Albert, J., Alexiev, I., Garcia, F., Struck, D., Vercautere, J., Van de Vijver, D., Åsjö, B., Balotta, C., Beshkov, D., Camacho, R., Coughlan, S., Griskevicius, A., Hamouda, O., Horban, A., Kolupajeva, T., Kostrikis, L., Kücherer, C., Liitsola, K., Linka, M., Mor, O., Nielsen, C., Otelea, D., Paraskevis, D., Paredes, R., Poljak, M., Puchhammer-Stöckl, E., Sönnerborg, A., Staneková, D., Stanojevic, M., Vandamme, A., ZidovecLepej, S., Boucher, C., Schmit, J.C. and Wensing, A. (2013) Increasing Number of HIV-1 Diagnoses with Transmitted Drug Resistance across Europe Despite Stable Prevalence. 14th European AIDS Conference, Brussels, 16-19 October 2013.

[117] Gupta, R.K., Jordan, M.R., Sultan, B.J., Daniel, A.H., Davis, H.J., Gregson, J., Sawyer, A.W., Hamers, R.L., Ndembi, N., Pillay, D. and Bertagnolio, S. (2012) Global Trends in Antiretroviral Resistance in Treatment-Naive Individuals with HIV after Rollout of Antiretroviral Treatment in Resource-Limited Settings: A Global Collaborative Study and Meta-Regression Analysis. Lancet, 380, 1250-1258

[118] World Health Organization (2012) WHO HIV Drug Resistance Report 2012. http://apps.who.int/iris/bitstream/10665/75183/1/9789241503938_eng.pdf

[119] Drescher, S.M., von Wyl, V., Yang, W.L., Böni, J., Yerly, S., Shah, C., Aubert, V., Klimkait, T., Taffé, P., Furrer, H., Battegay, M., Ambrosioni, J., Cavassini, M., Bernasconi, E., Vernazza, P.L., Ledergerber, B. and Kouyos, R.D. (2013) Treatment-Naive Individuals Are the Major Source of Transmitted HIV-1 Drug-Resistance in MSMs in the Swiss HIV Cohort Study. Clinical Infectious Diseases, 58, 285-294. http://dx.doi.org/10.1093/cid/cit694

[120] CDC, USA (2011) High-Impact HIV Prevention: CDC's Approach to Reducing HIV Infections in the United States. http://www.cdc.gov/hiv/pdf/policies NHPC Booklet.pdf

[121] Choopanya, K., Martin, M., Suntharasamai, P., Sangkum, U., Mock, P.A., Leethochawalit, M., Chiamwongpaet, S., Kitisin, P., Natrujirote, P., Kittimunkong, S., Chuachoowong, R., Gvetadze, R.J., McNicholl, J.M., Paxton, L.A., Curlin, M.E., Hendrix, C.W., Vanichseni, S. for the Bangkok Tenofovir Study Group (2013)Antiretroviral Prophylaxis for 
HIV Infection in Injecting Drug Users in Bangkok, Thailand (the Bangkok Tenofovir Study): A Randomised, DoubleBlind, Placebo-Controlled Phase 3 Trial. Lancet, 381, 2083-2090. http://dx.doi.org/10.1016/S0140-6736(13)61127-7

[122] Zule, W.A., Cross, H.E., Stover, J. and Pretorius, C. (2013) Are Major Reductions in New HIV Infections Possible with People Who Inject Drugs? The Case for Low Dead-Space Syringes in Highly Affected Countries. International Journal of Drug Policy, 24, 1-7. http://dx.doi.org/10.1016/j.drugpo.2012.07.002

[123] CDC, USA (2012) Integrated Prevention Services for HIV Infection, Viral Hepatitis, Sexually Transmitted Diseases, and Tuberculosis for Persons Who Use Drugs Illicitly: Summary Guidance from CDC and the U.S. Department of Health and Human Services. Recommendations and Reports, Morbidity and Mortality Weekly Report (MMWR), 61, 1-40. http://www.cdc.gov/mmwr/preview/mmwrhtml/rr6105a1.htm?s_cid=rr6105a1_w.

[124] Go, V., Frangakis, C., Nguyen Le, M., Tran Viet, H., Latkin, C., Tran Thi, M., Sripaipan, T., Davis, W., Pham The, V. and Vu Minh, Q. (2012) Effects of an HIV/AIDS Peer Prevention Intervention on Sexual and Injecting Risk Behaviours among Injecting Drug Users (IDU) and Their Risk Partners in Thai Nguyen, Vietnam: A Randomized Controlled Trial. Nineteenth International AIDS Conference, Washington DC, abstract THAC0404. http://pag.aids2012.org/Abstracts.aspx?SID=267\&AID=18303

[125] Fisher, M., Pao, D., Brown, A.E., Sudarshi, D., Gill, O.N., Cane, P., Buckton, A.J., Parry, J.V., Johnson, A.M., Sabin, C. and Pillay, D. (2010) Determinants of HIV-1 Transmission in Men Who Have Sex with Men: A Combined Clinical, Epidemiological and Phylogenetic Approach. AIDS, 24, 1739-1747. http://dx.doi.org/10.1097/QAD.0b013e32833ac9e6

[126] Miller, V. (2008) Comment on “CDC Recommendations for Routine HIV Testing Largely Ignored”. At the Forum for Collaborative HIV Research, Arlington, Virginia. http://www.medicalnewstoday.com/articles/130267.php

[127] Hall, H.I., Holtgrave, D.R. and Maulsby, C. (2012) HIV Transmission Rates from Persons Living with HIV Who Are Aware and Unaware of Their Infection. AIDS, 26, 893-896. http://dx.doi.org/10.1097/QAD.0b013e328351f73f

[128] Lucas, A. and Armbruster, B. (2013) The Cost-Effectiveness of Expanded HIV Screening in the US. AIDS, 27, 795801. http://dx.doi.org/10.1097/QAD.0b013e32835c54f9

[129] European Centre for Disease and Prevention Control-ECDC Corporate (2010) Strategies for Disease Specific Programs 2010-2013.

http://ecdc.europa.eu/en/publications/Publications/100714_COR_Strategies_for_disease-specific_programmes_2010-2 013.pdf

[130] US Preventive Services Task Force (USPSTF) (2013) Universal HIV Screening Recommended by USPSTF. (Annals of Internal Medicine) http://www.uspreventiveservicestaskforce.org/uspstf13/hiv/hivfinalrs.htm

[131] Margolis, A.D., Joseph, H., Belcher, L., Hirshfield, S. and Chiasson, M.A. (2012) ‘Never Testing for HIV’ among Men Who Have Sex with Men Recruited from a Sexual Networking Website, United States. AIDS and Behavior, 16, $23-29$. http://dx.doi.org/10.1007/s10461-011-9883-4

[132] Health Protection Agency/HPA (2012) HIV in the United Kingdom: 2012 Report. http://www.hpa.org.uk/webc/HPAwebFile/HPAweb_C/1317137200016

[133] Mocroft, A., Lundgren, J.D., Sabin, M.L., Monforte, A.D.A., Brockmeyer, N., Casabona, J., Castagna, A., Costagliola, D., Dabis, F., De Wit, S., Fätkenheuer, G., Furrer, H., Johnson, A.M., Lazanas, M.K., Leport, C., Moreno, S., Obel, N., Post, F.A., Reekie, J., Reiss, P., Sabin, C., Skaletz-Rorowski, A., Suarez-Lozano, I., Torti, C., Warszawski, J., Zangerle, R., Fabre-Colin, C., Kjaer, J., Chene, G., Grarup, J., Kirk, O. and Collaboration of Observational HIV Epidemiological Research Europe (COHERE) Study in EuroCoord (2013) Risk Factors and Outcomes for Late Presentation for HIV-Positive Persons in Europe: Results from the Collaboration of Observational HIV Epidemiological Research Europe Study (COHERE). PLoS Medicine, 10, Article ID: e1001510.

[134] Tucker, J.D., Wong, F.Y., Nehl, E.J. and Zhang, F.J. (2012) HIV Testing and Care Systems Focused on Sexually Transmitted HIV in China. Sexually Transmitted Infections, 88, 116-119. http://dx.doi.org/10.1136/sextrans-2011-050135

[135] Wang, Y., Chinese Center for Disease and Control Prevention, P.R. China (2012) Health Official Calls for Real-Name HIV Testing. http://news.xinhuanet.com/english/china/2012-02/08/c_131398944.htm

[136] Dennin, R.H., Lafrenz, M., Sinn, A. and Li, L.J. (2011) Dilemma of Concepts and Strategies for the Prevention of the Spread of HIV in Relation to Human Behavior, Law and Human Rights. Journal of Zhejiang University Science B, 12, 591-610. http://dx.doi.org/10.1631/jzus.B1000434

[137] Sullivan, P.S., Carballo-Diéguez, A., Coates, T., Goodreau, S.M., McGowan, I., Sanders, E.J., Smith, A., Goswami, P. and Sanchez, J. (2012) Successes and Challenges of HIV Prevention in Men Who Have Sex with Men. Lancet, 380, 388-399. http://dx.doi.org/10.1016/S0140-6736(12)60955-6

[138] Del Rio, C. (2012) Understanding and Addressing Cultural and Socioeconomic Barriers to Effective HIV Management. International AIDS Conference, Washington, HPTN 061.

https://www.clinicaloptions.com/HIV/Treatment\%20Updates/Cultural\%20Barriers/Module/Cultural_Barriers.aspx 
[139] Vermund, S.H., Allen, K.L. and Karim, Q.A. (2009) HIV-Prevention Science at a Crossroads: Advances in Reducing Sexual Risk. Current Opinion in HIV \& AIDS, 4, 266-273. http://dx.doi.org/10.1097/COH.0b013e32832c91dd

[140] Ortblad, K.F., Lozano, R. and Murray, C.J. (2013) The Burden of HIV: Insights from the Global Burden of Disease Study 2010. AIDS, 27, 2003-2017. http://dx.doi.org/10.1097/QAD.0b013e328362ba67

[141] Ruan, B. and Li, L.J. (Head of Study Group) (2011) The Mega-Project for National Science and Technology Development under the 11th and 12th Five-Year Plan of China, Subtitled: The Epidemiology, Prevention and Control of Key Infectious Diseases such as AIDS and Hepatitis on the Social Population in Zhejiang Province, China. (2009ZX10004901, 2011ZX10004-901, 2013ZX10004-904). Details are available via email hzruanbing@163.com.

[142] Pebody, R. (2013) Low Uptake of Behavioural Interventions by Gay Men at English Sexual Health Clinics. In: Desai, M., Desai, S., Sullivan, A.K., Mohabeer, M., Mercey, D., Kingston, M.K., Thng, C., McCormack, S., Gill, O.N. and Nardone, A., Eds., Audit of HIV Testing Frequency and Behavioural Interventions for Men Who Have sex with Men: Policy and Practice in Sexual Health Clinics in England. Sexually Transmitted Infections, published online first, January 2013, AIDS Map 2012. http://dx.doi.org/10.1136/sextrans-2012-050679 http://www.aidsmap.com/Low-uptake-of-behavioural-interventions-by-gay-men-at-English-sexual-health-clinics/page/ 2563196/

[143] Jemmott, L.S., Jemmott III, J.B. and O’Leary, A. (2007) Effects of Sexual Risk Behaviour and STD Rate of Brief HIV/STD Prevention Interventions for African American Women in Primary Health Settings. American Journal of Public Health, 97, 1034-1040. http://dx.doi.org/10.2105/AJPH.2003.020271

[144] Birrell, P.J., Gill, O.N., Delpech, V.C., Brown, A.E., Desai, S., Chadborn, T.R., Rice, B.D. and De Angelis, D. (2013) HIV Incidence in Men Who Have Sex with Men in England and Wales 2001-10: A Nationwide Population Study. Lancet Infectious Diseases, 13, 313-318. http://dx.doi.org/10.1016/S1473-3099(12)70341-9

[145] Sood, N., Wagner, Z., Jaycocks, A., Drabo, E. and Vardavas, R. (2013) Test-and-Treat in Los Angeles: A Mathematical Model of the Effects of Test-and-Treat for the Population of Men Who Have Sex with Men in Los Angeles County. Clinical Infectious Diseases, 56, 1789-1796. http://dx.doi.org/10.1093/cid/cit158

[146] Soeters, H.M., Napravnik, S., Zakharova, O.M., Eron, J.J. and Hurt, C.B. (2013) Opportunities for Sexual Transmission of Antiretroviral Drug Resistance among HIV-Infected Patients in Care. AIDS, 27, 2873-2881. http://dx.doi.org/10.1097/01.aids.0000433240.78739.30

[147] AIDSmap, a Comment on HIV \& the Criminal Law. Challenges Associated with Disclosingone’s HIV-Positive Status. http://www.aidsmap.com/Challenges-associated-with-disclosing-ones-HIV-positive-status/page/1442642

[148] Galletly, C.L. and Pinkerton, S.D. (2006) Conflicting Messages: How Criminal HIV Disclosure Laws Undermine Public Health Efforts to Control the Spread of HIV. AIDS and Behavior, 10, 451-461. http://dx.doi.org/10.1007/s10461-006-9117-3

[149] UNAIDS, February 2012, Revised Version on Criminalisation of HIV Non-Disclosure, Exposure and Transmission: Scientific, Medical, Legal and Human Rights Issues. Geneva, 31 August-2 September 2011.

http://www.unaids.org/en/media/unaids/contentassets/documents/document/2012/KeyScientificMedicalLegalIssuesCri minalisationHIV_final.pdf

http://www.unaids.org/en/media/unaids/contentassets/documents/document/2013/05/20130530_Guidance_Ending_Cri minalisation.pdf

[150] Phillips, M. and Sukthankar, A. (2013) Imprisonment for Non-Intentional Transmission of HIV: Can It Be Supported Using Established Principles for Justifying Criminal Sentencing? Sexually Transmitted Infections, 89, 276-279. http://dx.doi.org/10.1136/sextrans-2012-050978

[151] Lazzarini, Z., Bray, S. and Burries, S. (2002) Evaluation the Impact of Criminal Laws on HIV Risk Behavior. Journal of Law, Medicine \& Ethics, 30, 239-253. http://dx.doi.org/10.1111/j.1748-720X.2002.tb00390.x

[152] ECHR, Commented by Westeson, ECHR (II. Section) (2005) Verdict Dated January 25, 2005-No. 56529/00 (Enhorn/Sweden) Rn. 44.

[153] Pillay, D., Rambaut, A., Geretti, A.M. and Brown, A.J.L. (2007) HIV Phylogenetics, Criminal Convictions Relying Solely on This to Establish Transmission Are Unsafe. British Medical Journal, 335, 460-461. http://dx.doi.org/10.1136/bmj.39315.398843.BE

[154] NAM aidsmap, A Leaflet Concerning HIV Transmission. The Basics_-Transmission and the Law. http://www.aidsmap.com/v634665448501870000/file/1052030/Transmission_and_the_law.pdf

[155] Baltimore, D. (1995) The Enigma of HIV Infection. Cell, 82, 175-176. http://dx.doi.org/10.1016/0092-8674(95)90303-8

[156] De Groot, N.G. and Bontrop, R. (2013) The HIV-1 Pandemic: Does the Selective Sweep in Chimpanzees Mirror Humankind's Future? Retrovirology, 10, 53. http://dx.doi.org/10.1186/1742-4690-10-53.

[157] Kintziger, K.W. and Duffus, W.A. (2014) How Useful Is Universal Screening for HIV Infection? A Review of the 
Evidence. Future Virology, 9, 131-145. http://www.medscape.com/viewarticle/822238_1 http://dx.doi.org/10.2217/fvl.13.122

[158] Ross, L.L., Horton, J., Hasan, S., Brown, J.R., Murphy, D., DeJesus, E., Potter, M., LaMarca, A., Melendez-Rivera, I., Ward, D., Uy, J. and Shaefer, M.S. (2014) HIV-1 Transmission Patterns in Antiretroviral Therapy-Naïve, HIV-Infected North Americans Based on Phylogenetic Analysis by Population Level and Ultra-Deep DNA Sequencing. PLoS ONE, 9, Article ID: e89611. http://dx.doi.org/10.1371/journal.pone.0089611 


\section{Supplements}

Human Immunodeficiency Virus (HIV) 1/2: the transmission among humans happens mainly by sexual activities of diverse varieties and injecting drug use. HIV is a retrovirus that mainly infects cells of the human immune system, e.g., certain $\mathrm{CD}^{+} \mathrm{T}$ cells which are named T-helper cells because of their function in organizing the adaptive immune response. After infection of the cells and reverse transcription of its RNA genome into a double stranded DNA copy, this cDNA becomes integrated into the cellular genome. The Acute Retroviral Syndrome (ARS) weeks after infection does not show up in all infected people. Years after the infection with/without nonspecific symptoms, the final stage of AIDS develops. AIDS stands for Acquired Immune Deficiency Syndrome, i.e., it is not a disease entity. From the time of the primary infection the immune system gets weakened; a surrogate marker for that is the concentration of $\mathrm{CD}^{+} \mathrm{T}$ cells in the blood. The $\mathrm{CD} 4^{+} \mathrm{T}$ cell count declines from around 1000 per $\mu$ l blood (in healthy persons) down to below 100 per $\mu \mathrm{l}$ and even less if the HIV infected patient remains untreated with antiretroviral drugs (Antiretroviral Therapy/ART). The concentration of HIV RNA/ml blood plasma (the viral load/VL) increases over the course of time. Because the immune system is weakened, the patients progressively suffer from, e.g., infectious diseases, new infections from the outside and the opportunistic infections (OI) already inside the body. OI established in the body are kept in check by the individual's immune system as long as it works.

The Hepatitis C Virus causes systemic infection in humans. Its infection mainly causes the liver disease Hepatitis C. However, the hepatocytes are not only the target cells because there are extrahepatic diseases, e.g., mixed cryoglobulinemia, which is believed to be causally associated with an HCV infection. The official nomenclature lists six genotypes and numerous geno-subtypes within. Genotypes must be taken into account regarding the disease progression and the standard of care treatment. By making use of the new generation of Direct Acting Antivirals (DAA) a real cure looks promising. The HCV gets transmitted through infected blood, e.g., by injecting drug users using needles and/or syringes contaminated with infected blood, or engaging in unprotected sexual intercourse with an infected partner, whereby the odds of transmitting an infection are high for anal intercourse and (very!) low for vaginal intercourse. Depending on various conditions, the onset of an acute disease develops in approximately $20 \%$ of infected people, i.e., about $80 \%$ with persistent viremia do not show clinical symptoms for years up to decades and may be infectious for other people. During this time of chronic infection a chronic liver disease may develop culminating in liver end-stage disease and liver cancer (HCC) in low percentages per year.

Syphilis is listed as a sexually transmitted infection (STI) caused by the bacteria Treponema pallidum. It is predominantly transmitted by all kinds of unprotected sexual practices. The sores occurring after infection are present mostly in genital areas and extragenital areas likewise. They constitute the main infectious sources. In addition, mother-to-child transmission can happen in utero. Because T. pallidum can be present in the blood, blood donations have to be tested for this agent with licensed test kits.

Human papilloma viruses (HPV) are DNA viruses. More than 100 genotypes are known. Because they are easily transmitted by smear infections via lesions of the skin and mucous membranes of the mouth and the genital tract, HPV show high prevalence in the human population. In particular, this is to be seen in the context of HIV and the sexual routes of transmission. Clinical manifestations range from benign warts to malign tumors, e.g., cervical cancer, depending on the genotype.

\section{Abbreviations}

ART, antiretroviral therapy; CCL, Chinese Criminal Law; CDC, Centre of Disease and Prevention Control/USA; CRF, Circulating Recombinant Form; ECDC, European Centre of Disease and Prevention Control; EEA, European Economic Area; EU, European Union; ECHR, European Court of Human Rights; GALT, gut associated lymphoid tissue; HAART, highly active antiretroviral therapy; MDR, multi drug resistance; MSM, men-sexwith-men; STI, sexual transmitted infections; TASP, treatment as prevention; TDR, transmitted drug resistance; UAI, unprotected anal intercourse. 
Scientific Research Publishing (SCIRP) is one of the largest Open Access journal publishers. It is currently publishing more than 200 open access, online, peer-reviewed journals covering a wide range of academic disciplines. SCIRP serves the worldwide academic communities and contributes to the progress and application of science with its publication.

Other selected journals from SCIRP are listed as below. Submit your manuscript to us via either submit@scirp.org or Online Submission Portal.
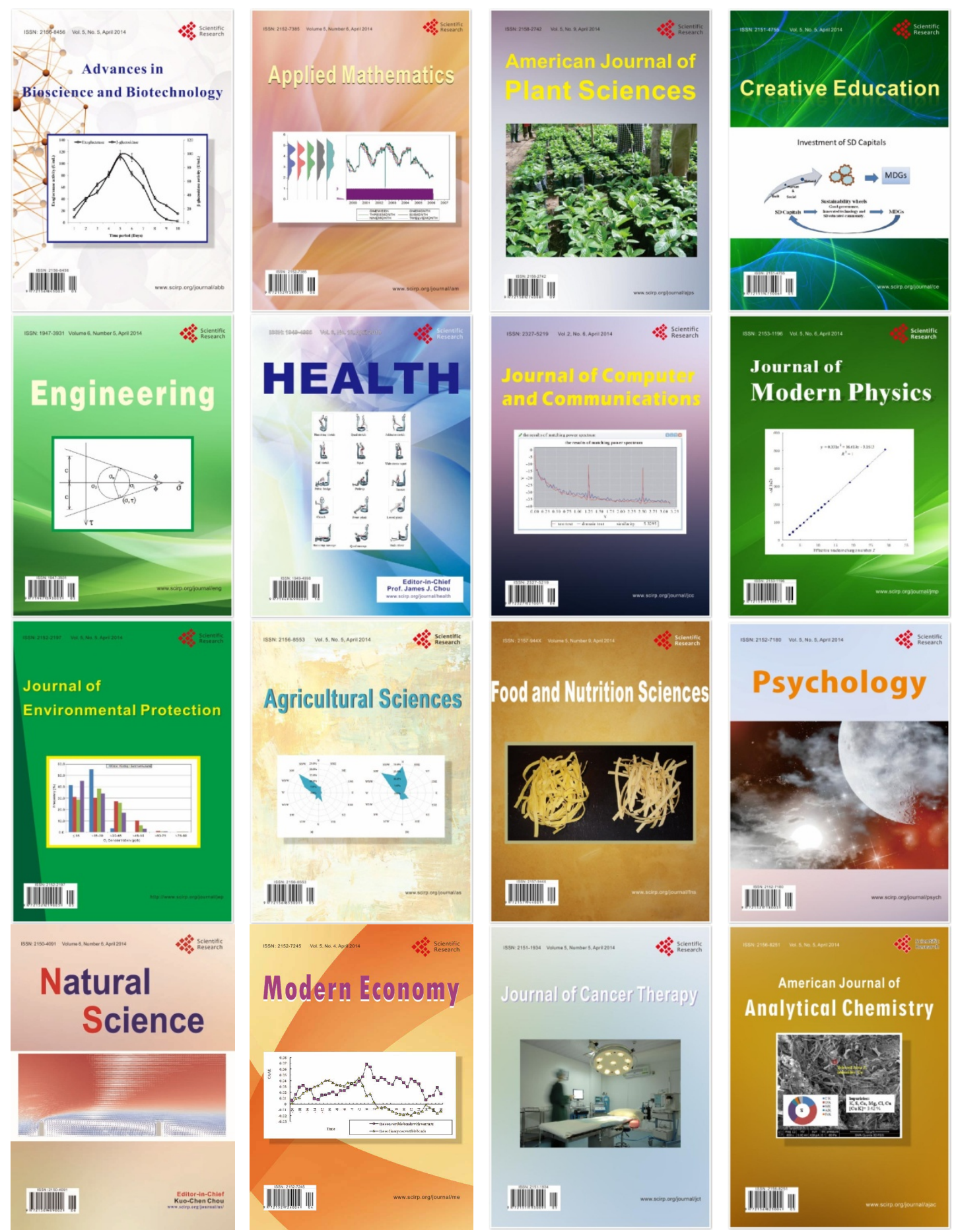